\title{
Sr and Nd isotope ratios and REE abundances of moraines in the mountain areas surrounding the Taklimakan Desert, NW China
}

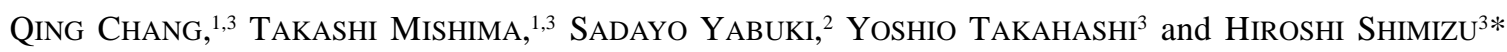 \\ ${ }^{1}$ Department of Environmental Science, Graduate School of Science and Technology, Kumamoto University, \\ Kumamoto 860-8555, Japan \\ ${ }^{2}$ The Institute of Physical and Chemical Research (RIKEN), Saitama 351-0198, Japan \\ ${ }^{3}$ Department of Earth and Planetary Sciences, Graduate School of Science, Hiroshima University, \\ Higashi-Hiroshima 739-8526, Japan
}

(Received March 29, 2000; Accepted August 28, 2000)

\begin{abstract}
The first systematic data of $\mathrm{Sr}$ and $\mathrm{Nd}$ isotopic ratios, REE abundances, major element and mineral compositions are reported for the Chinese moraines from the western Kunlun Mts. and southern and northern flanks of the Tianshan Mts. and soils from the Tibet Plateau. This study was conducted in order to characterize the isotopic and geochemical features of these moraines and soils, which are considered as possible sources of the Taklimakan Desert sands. The moraines and the desert sands consist of quartz and feldspar as dominant minerals, but the former have higher clay and mica and lower carbonate mineral abundances than the latter. In spite of the wide variation, average values of most major elements of the moraines are generally similar to those of the Taklimakan Desert sands, except for $\mathrm{CaO}$ depletion and $\mathrm{K}_{2} \mathrm{O}$ enrichment in the moraines. $\mathrm{Sr}$ and $\mathrm{Nd}$ isotopic ratios are also highly variable for moraines, particularly from the Tianshan northern flank, while those for the desert sands show restricted values. In the $\mathrm{Sr}-\mathrm{Nd}$ isotopic diagram, the Taklimakan Desert sands are plotted in the narrow field overlapped by both the moraine matrices from the western Kunlun Mts. and from the Tianshan southern flank. In addition, it is noted that average value of $\mathrm{Nd}$ isotopic ratios for the moraines is clearly higher than those for the desert sands. Two Tibetan soils of this study show wide variation in mineral composition and major element compositions $\left(\mathrm{SiO}_{2}=75 \%\right.$ and $\mathrm{CaO}=1.5 \%$ for one sample and $\mathrm{SiO}_{2}=44 \%$ and $\mathrm{CaO}=31.8 \%$ for the other). However, $\mathrm{Sr}$ isotopic ratios of both soils are similar to those of the desert sands and their $\mathrm{Nd}$ isotopic data are slightly smaller than the desert sands. These results suggest moraine matrices from both the western Kunlun Mts. and the Tianshan southern flank and the Tibetan soils as possible sources for the Taklimakan Desert sands.
\end{abstract}

\section{INTRODUCTION}

Glacial moraines in the surrounding mountain areas of the Taklimakan Desert are expected to bear important information on source material composition and formation mechanism of the desert sand. Glacial grinding has been proposed to be a main mechanism responsible for the formation of fine particles in huge amounts and large distribution scale (Smalley, 1966; Smalley and Vita-Finzi, 1968). Recent study on geochemical, mineralogical and sedimentological features of the Taklimakan Desert sands confirmed the importance of glacial activity besides aeolian activity in the homogenization of the Taklimakan Desert sands (Honda and Shimizu, 1998). However, direct investigation on the moraine deposits surrounding the Taklimakan Desert has been very scarce.

The Taklimakan Desert, located in the central of Tarim Basin in northwest China, is the largest sand desert in China, with a total area about

*Corresponding author (e-mail: shimizu@geol.sci.hiroshima-u.ac.jp) 


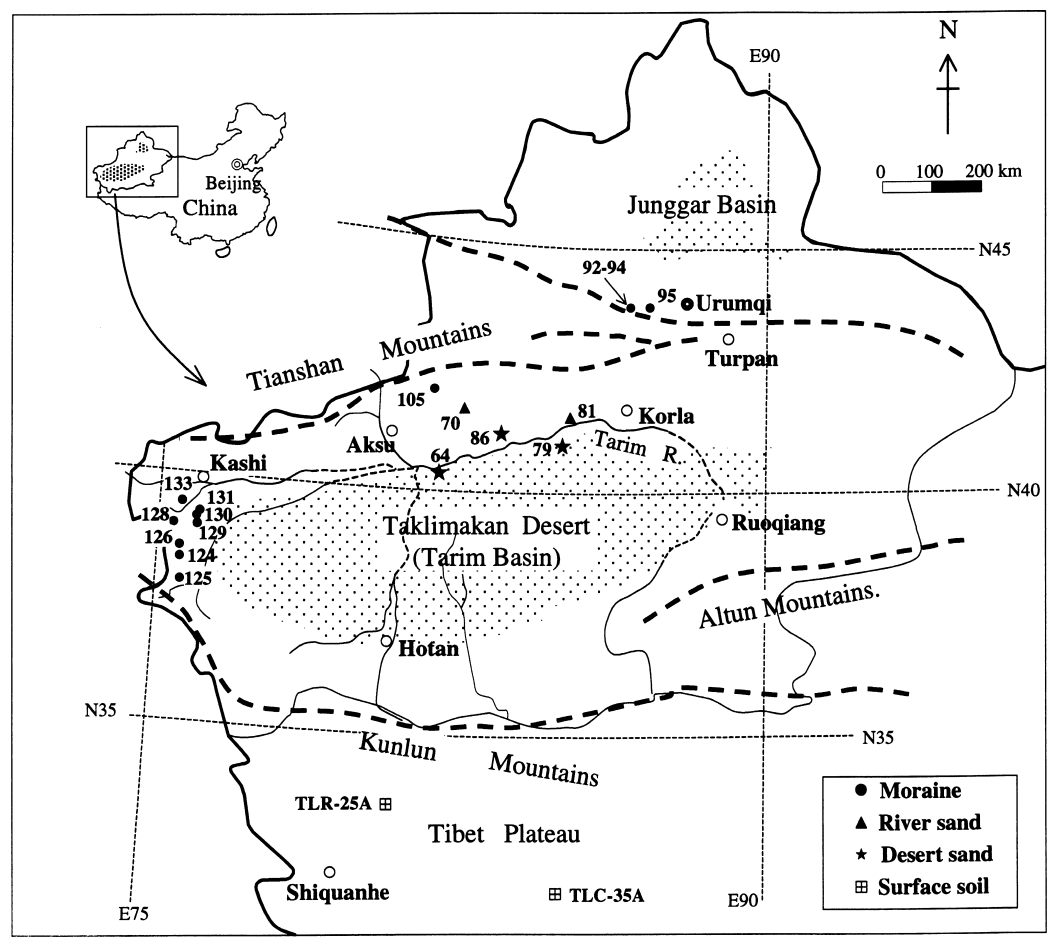

Fig. 1. Location of the Taklimakan Desert, Tianshan Mountains and Kunlun Mountains, with sampling sites.

$337,000 \mathrm{~km}^{2}$. Unlike other sand deserts in the world, it is enclosed by high mountains, i.e., the Tianshan Mts. in the north and the Kunlun and Altun Mts. in the south and southeast (Fig. 1). In these mountains, the glaciation was inferred to be extensive and much larger in the late Pliocene and Pleistocene than present (Zheng et al., 1990; Xinjiang Institute of Geography, 1986). Larger glaciers including big ice cap occupying the main Kunlun Mts. formed during Middle Pleistocene (Zheng et al., 1990; Derbyshire, 1996). The existence of Late Pleistocene glacial deposits of approximately $60 \mathrm{~m}$ in thickness, on the southern flank of the Tianshan Mts., was reported by the Xinjiang Institute of Geography (1986). It is also reported that multiple glaciations had occurred during the Pleistocene in Kunlun Mts. with glacier extent changing from restricted valleys as mountain glaciation to large areas as ice sheet glaciation (Derbyshire, 1996). The widespread glaciation in these mountain areas as well as the close location and large altitude gap between the desert and the mountain areas further enhances the probability that a huge quantity of sand grains was principally derived from detrital sediments produced by glacial grinding in the surrounding mountain areas.

$\mathrm{Sr}$ and $\mathrm{Nd}$ isotopic compositions of sediments may provide useful information about their source materials. Liu et al. (1994) measured the Rb-Sr, Sm-Nd and La-Ce isotopic compositions for the loess, loess-like, desert sand and river deposits collected from the southwest Taklimakan Desert. They showed that the desert sands of the Taklimakan Desert and loess of the Loess Plateau are indistinguishable in $\mathrm{Nd}$ isotopic and chemical compositions, and suggested a desert origin for the Chinese loess and the Taklimakan Desert as the source area. Isotopic study on moraine matrix, representing average components of glacial grinding products, is expected to shed insight into the source and formation and homogenous mechanism of desert sands and loesses. Limited investigations on the moraine deposits of these areas had 
been done thus far. Ishii et al. (1995) studied the distribution, petrologic features and oxygen isotope composition of moraine deposits surrounding the Taklimakan Desert. Matsuhisa et al. (1996) compared the $\delta^{18} \mathrm{O}$ values of quartz in loess, moraine and basement rock of Tarim Basin, and proposed a descriptive model concerning derivation of sand grains, i.e., fine particles could be formed initially by glacial erosion then deposited as moraine matrix and finally transported to the desert.

Until the present, systematic geochemical and $\mathrm{Sr}-\mathrm{Nd}$ isotopic study has not been carried out for the Chinese moraines. Knowledge on source materials of the Taklimakan Desert sands is still very poor. In this paper, we presented new results of $\mathrm{Sr}$ and Nd isotopic compositions, REE abundances, major element and mineral compositions for moraines in surrounding mountain areas of the Taklimakan Desert as well as for the Taklimakan Desert sands. Surface soil samples from the northwest Tibet Plateau were also analyzed. Accumulation of these geochemical and isotopic data will give information on the relative contribution of the moraines against other possible sources to the Taklimakan Desert sands, even though some uncertainties of the extent of the Pleistocene glaciation in the Kunlun and Tianshan Mts. are present.

\section{SAMPles ANd AnAlytical Methods}

The moraine matrix in the surrounding mountain areas of Taklimakan Desert is mainly the mixture of basement rock detritus derived from glacial grinding and sedimentation. It represents an average composition of sedimentary rocks (chiefly sandstone, shale and limestone) from Precambrian to Quaternary ages and granitic rocks from the Proterozoic to Cretaceous (Bureau of Geology and Mineral Resources of Xinjiang Uygur Autonomous Region, 1993). The moraine samples of this study were collected from Gez and Karakuri Lake areas in west Kunlun Mountains, and Bosten and No. 1 Glacier areas in the south and north flanks of Tianshan Mountains (Fig. 1 and Table 1). Surface soil samples from northwest Tibet Plateau were collected at Duoma and Daxiong. In addi- tion, three desert sand and two river sand samples from the northern part of the Taklimakan Desert were examined to complement the limited existing reference data for the Taklimakan Desert sand (Liu et al., 1994; Tanaka et al., 1990). The possible size effects on isotopic ratio and REE concentration are examined in this study for size fractions relatively coarser (from $>500 \mu \mathrm{m}$ to $32-20$ $\mu \mathrm{m}$ ) than those in previous studies (e.g., Basile et al., 1997 and Asahara et al., 1999 for Sr isotope; Goldstein et al., 1984 and Grousset et al., 1992 for $\mathrm{Nd}$ isotope).

Major element abundance was determined using X-ray fluorescence spectrometer (XRF, Shimadzu VF-320A) by the method given by Honda and Shimizu (1998). Repeated analyses of standard rocks showed the precision to be better than $1 \%$ for $\mathrm{SiO}_{2}$ and $3-5 \%$ for other major elements. Mineralogical composition of powdered sample was determined by X-ray diffraction (XRD, Mac Science M18XHF-SRA 1180) and checked by microscopic examination for coarser grains. Mineral abundance was estimated from the best fitting of major elements composition with the XRD identification.

Concentrations of REE, $\mathrm{Rb}$ and $\mathrm{Sr}$ were determined by inductively coupled plasma mass spectrometer (ICP-MS, VG PQ3), and Sr and Nd isotopic ratios were measured by thermal ionization mass spectrometer (TIMS, VG Sector-54) with three Faraday collectors at the Institute of Physical and Chemical Research. The analytical methods were given in Shimizu et al. (2000). Analytical uncertainties are $3 \%$ for $\mathrm{Rb}$ and $\mathrm{Sr}$ concentrations and $5 \%$ for most REE. Blanks on REE determination were less than $0.1 \%$ of measured values of all REE. The measured isotopic ratios were normalized to ${ }^{86} \mathrm{Sr} /{ }^{88} \mathrm{Sr}=0.1194$ and ${ }^{146} \mathrm{Nd} /$ ${ }^{144} \mathrm{Nd}=0.7219$. The average for the NBS987 strontium standard was $0.71024 \pm 0.00002(2 \sigma$, $n=18$ ), and for JNdi-1 neodymium standard of Geology Survey of Japan (Tanaka et al., 1996) was $0.51210 \pm 0.00001(2 \sigma, n=15)$ during the measurement. The ${ }^{143} \mathrm{Nd} /{ }^{144} \mathrm{Nd}$ ratios for the JNdi-1 standard and La Jolla standard have been reported to be $0.512106 \pm 0.000003(2 \sigma)$ and $0.511851 \pm$ 
Table 1. Sample descriptions

\begin{tabular}{|c|c|c|c|}
\hline Sample No. & Location & Location No. & Brief description \\
\hline \multicolumn{4}{|c|}{ Moraines of north Tianshan Mts. } \\
\hline 9301 & end position of No. 1 glacier & 92 & fine fraction \\
\hline 9302 & end position of No. 1 glacier & 93 & fine fraction \\
\hline 9304 & lower reach of No. 1 glacier & 94 & matrix \\
\hline 9305 & left bank of Urumqi River & 95 & fine fraction \\
\hline \multicolumn{4}{|c|}{ Moraines of south Tianshan Mts. } \\
\hline $9315-2 \mathrm{M}$ & north of Bosten & 105 & matrix \\
\hline $9315-\mathrm{G}$ & north of Bosten & 105 & gravel \\
\hline \multicolumn{4}{|c|}{ Moraines of west Kunlun Mts. } \\
\hline $9404-2$ & Subashi Pass & 125 & matrix, $80-380 \mathrm{~cm}$ in depth \\
\hline $9403-3$ & Karakuri Lake & 124 & grey silt, $40-70 \mathrm{~cm}$ in depth \\
\hline 9405 & Karakuri Lake & 126 & ancient moraine matrix, $60 \mathrm{~cm}$ \\
\hline $9407-2$ & Karakuri Lake & 128 & grey, matrix, $33 \mathrm{~cm}$ in depth \\
\hline $9408-2$ & $\mathrm{Gez}$ & 129 & grey, $\mathrm{M} 3$ moraine matrix, $1 \mathrm{~m}+$ thickness \\
\hline $9408-3$ & $\mathrm{Gez}$ & 129 & outwash of M3 moraine, silt \\
\hline 9409 & $\mathrm{Gez}$ & 130 & matrix of M1 moraine \\
\hline $9410-2$ & Gez & 131 & grey, matrix \\
\hline $9412-1$ & Oytag & 133 & black, matrix \\
\hline \multicolumn{4}{|c|}{ Sands of north Taklimakan Desert } \\
\hline 9206 & Luntai & 79 & barchan sand \\
\hline A92501-A & Aral & 64 & dune sand \\
\hline 9213 & Shaya & 86 & barchan sand \\
\hline A92802 & Yakrik & 70 & river sand (Muzat River) \\
\hline 9208 & Luntai & 81 & river sand (Tarim River) \\
\hline \multicolumn{4}{|c|}{ Northwest Tibet soils } \\
\hline TLR-25A & Duoma, Tibet & & surface soil \\
\hline TLC-35A & Daxiong, Tibet & & surface soil \\
\hline
\end{tabular}

$0.000006(2 \sigma)$ by Miyazaki and Shuto (1998), and $0.512115 \pm 0.000016(2 \sigma)$ and $0.511857 \pm$ $0.000018(2 \sigma)$ by Dragusanu and Tanaka (1999). The procedure blank of chemical separation is estimated less than 1-2 $\mathrm{ng}$ for $\mathrm{Sr}$ and $0.2 \mathrm{ng}$ for $\mathrm{Nd}$. The blank values of $\mathrm{Sr}$ and $\mathrm{Nd}$ are both about $0.05 \%$ of the total and considered to be negligible in all isotopic measurements.

\section{RESULTS AND DISCUSSION}

\section{Mineralogical compositions}

Mineralogical compositions are presented in Table 2 and Fig. 2. Quartz and feldspars are the dominant minerals in moraine matrix, varying in $30-50 \%$ and $18-45 \%$, respectively. Calcite is iden- tified in varying abundance but generally $<5 \%$; two highest abundances about $15 \%$ are found in moraine from south flank of Tianshan Mts. (93152M) and west Kunlun Mts. (9412-1). Mica and kaolinite are also essential constituents of the moraines and their XRD peak ratios against quartz vary from 0.1 to 0.3 and from 0.02 to 0.3 , respectively. Some moraine samples contain gypsum and its content reaches to $15 \%$ in a Kunlun Mts. moraine sample of 9408-2. Tibet soils are quite variable in mineral composition; one shows high quartz content ( $\mathrm{ca} .55 \%)$ and the other shows high calcite content (ca. $43 \%$ ) besides quartz (ca. 26\%).

The moraines and desert sands are similar in feldspar content. Quartz and calcite are generally more abundant in desert sands than in moraines 
Table 2. Mineral composition (\%) and XRD peak ratios against quartzfor the Kunlun and Tianshan Mts. moraines, the Taklimakan Desert sands and Tibet soils

\begin{tabular}{|c|c|c|c|c|c|c|c|c|c|c|c|c|}
\hline \multirow[t]{2}{*}{ Sample No. } & \multicolumn{5}{|c|}{ Abundance $(\%)^{(\mathrm{a})}$} & \multicolumn{7}{|c|}{ Quartz relative XRD peak ratio ${ }^{(\mathrm{c})}$} \\
\hline & Quartz & Feldspar & Calcite & Gypsum & Others $^{(b)}$ & $\mathrm{Pl} / \mathrm{Q}$ & $\mathrm{Kf} / \mathrm{Q}$ & $\mathrm{Cal} / \mathrm{Q}$ & Gy/Q & Dol/Q & $\mathrm{Mi} / \mathrm{Q}$ & $\mathrm{Ka} / \mathrm{Q}$ \\
\hline \multicolumn{13}{|c|}{ Moraines of north Tianshan Mts. } \\
\hline 9301 & 32 & 24 & 2 & 0 & 43 & 0.26 & 0.09 & 0.03 & 0 & 0 & 0.24 & 0.17 \\
\hline 9302 & 41 & 23 & 0 & 0 & 36 & 0.28 & 0.24 & 0.01 & 0 & 0 & 0.20 & 0.09 \\
\hline 9304 & 30 & 33 & 0 & 0 & 37 & 0.92 & 0.49 & 0 & 0 & 0 & 0.07 & 0.12 \\
\hline 9305 & 42 & 22 & 6 & 0 & 31 & 0.10 & 0 & 0.09 & 0 & 0 & 0.10 & 0.27 \\
\hline \multicolumn{13}{|c|}{ Moraines of south Tianshan Mts. } \\
\hline $9315-2 \mathrm{M}$ & 37 & 24 & 13 & 3 & 23 & 0.43 & 0.24 & 0.27 & 0.13 & 0.08 & 0.11 & 0.09 \\
\hline $9315-\mathrm{G}$ & 27 & 45 & 5 & 0 & 23 & 1.36 & 1.63 & 0.10 & 0 & 0 & 0.13 & 0.06 \\
\hline \multicolumn{13}{|c|}{ Moraines of west Kunlun Mts. } \\
\hline $9404-2$ & 36 & 36 & 4 & $<1$ & 23 & 1.42 & 0.55 & 0.20 & 0 & 0 & 0.08 & 0.12 \\
\hline $9403-3$ & 43 & 23 & 2 & $<1$ & 31 & 0.92 & 0.74 & 0.02 & 0.01 & 0 & 0.29 & 0.03 \\
\hline 9405 & 38 & 19 & 5 & 0 & 38 & 0.49 & 0.20 & 0.11 & 0.03 & 0.03 & 0.32 & 0.07 \\
\hline $9407-2$ & 39 & 21 & 4 & 2 & 34 & 0.36 & 0.23 & 0.07 & 0.05 & 0 & 0.27 & 0.10 \\
\hline $9408-2$ & 43 & 22 & 0 & 15 & 20 & 0.80 & 0.44 & 0 & 0.99 & 0.11 & 0.23 & 0.05 \\
\hline $9408-3$ & 38 & 27 & 5 & $<1$ & 31 & 0.58 & 0.42 & 0.08 & 0 & 0.04 & 0.15 & 0.08 \\
\hline 9409 & 37 & 27 & 0 & 9 & 27 & 0.57 & 0.48 & 0 & 0.27 & 0 & 0.26 & 0.03 \\
\hline $9410-2$ & 49 & 22 & 0 & $<1$ & 29 & 0.32 & 0.53 & 0 & 0 & 0 & 0.14 & 0.02 \\
\hline $9412-1$ & 39 & 18 & 13 & 1 & 29 & 0.10 & 0 & 0.52 & 0 & 0.17 & 0.18 & 0.20 \\
\hline \multicolumn{13}{|c|}{ Sands of north Taklimakan Desert } \\
\hline 9206 & $49(48)$ & $25(32)$ & $6(7)$ & $<1$ & 19 & 1.00 & 0.29 & 0.17 & 0 & 0.05 & 0.04 & 0.03 \\
\hline A92501-A & $45(47)$ & $24(17)$ & $7(10)$ & $<1$ & 24 & 0.42 & 0.19 & 0.22 & 0 & 0.07 & 0.07 & 0.04 \\
\hline 9213 & $(29)$ & (24) & (33) & - & (14) & 0.18 & 0.10 & 1.04 & 0 & 0.19 & 0.07 & 0.04 \\
\hline A92802 & $38(41)$ & $18(20)$ & $29(18)$ & 0 & 15 & 0.17 & 0.10 & 0.83 & 0 & 0.32 & 0.10 & 0.04 \\
\hline 9208 & $48(44)$ & $20(12)$ & $11(10)$ & $<1$ & 20 & 0.27 & 0.21 & 0.45 & 0 & 0.17 & 0.07 & 0.05 \\
\hline \multicolumn{13}{|c|}{ Northwest Tibet soils } \\
\hline TLR-25A & 53 & 19 & 0 & 1 & 26 & 0.27 & 0.16 & 0.01 & 0 & 0.04 & 0.05 & 0.05 \\
\hline TLC-35A & 26 & 9 & 43 & 0 & 22 & 0.04 & 0 & 1.56 & 0 & 1.47 & 0.11 & 0.08 \\
\hline
\end{tabular}

${ }^{(a)}$ Numbers in brackets are point-counting results.

(b) Others include dolomite (mainly in the desert sands), kaolinite, mica, chlorite, hematite, epidote and amphibole minerals.

${ }^{(c)} Q=$ quartz, $P l=$ plagioclase, $K f=K$-feldspar, Cal = calcite, $G y=$ gypsum, Dol $=$ dolomite, $M i=$ mica, Ka $=$ kaolinite .

(Fig. 3), whereas mica and kaolinite are less abundant in desert sands (Table 2). Higher calcite contents in the desert sands than in moraines suggest an addition of secondary calcite to the desert sands. It is also found that dolomite occurs more commonly in the desert sand than in moraine. Hot and dry desert environments may favor the formation of dolomite from the evaporation of $\mathrm{Mg}$ rich saline solution (Deer et al., 1992). Low content of mica and kaolinite in the desert sands relative to moraines is likely to be the result of particle sorting.

$\mathrm{Mg}-\mathrm{Fe}$ chlorite, amphibolite, epidote and opaque minerals such as hematite are also ob- served in the moraine samples by microscopy observation and EPMA determination. They are rarely observed in the desert sands.

In the Taklimakan Desert sands of this study, quartz, feldspars and calcite are the main constituent commonly associated with mica and kaolinite. Quartz, feldspars and calcite contents are 40-50\%, $15-25 \%$ and $5-30 \%$, respectively. These mineral compositions for the sands from north side of the Taklimakan Desert are similar to those from south and central parts of the Taklimakan Desert (Honda and Shimizu, 1998), showing homogeneity in mineral compositions in the Taklimakan Desert. 


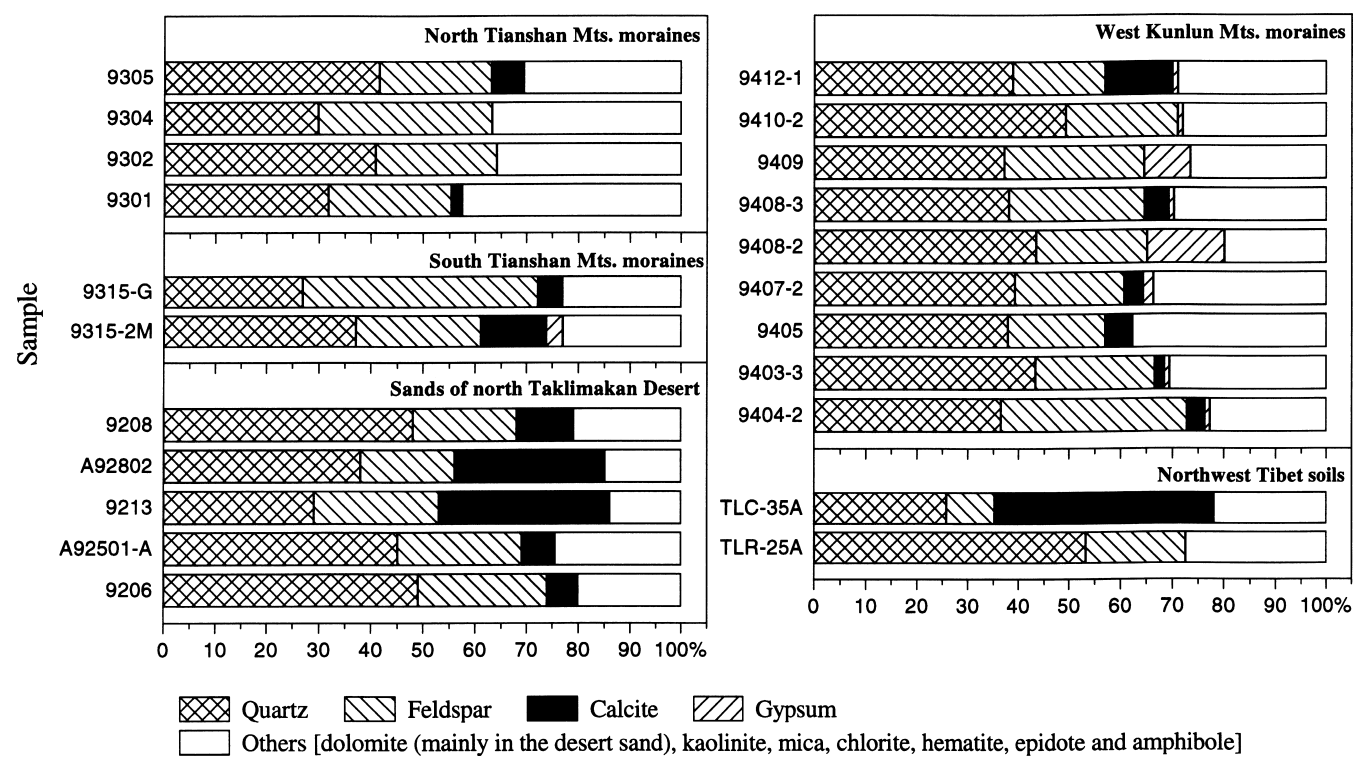

Fig. 2. Mineral compositions of the moraines, the desert sands and northwest Tibet soils.

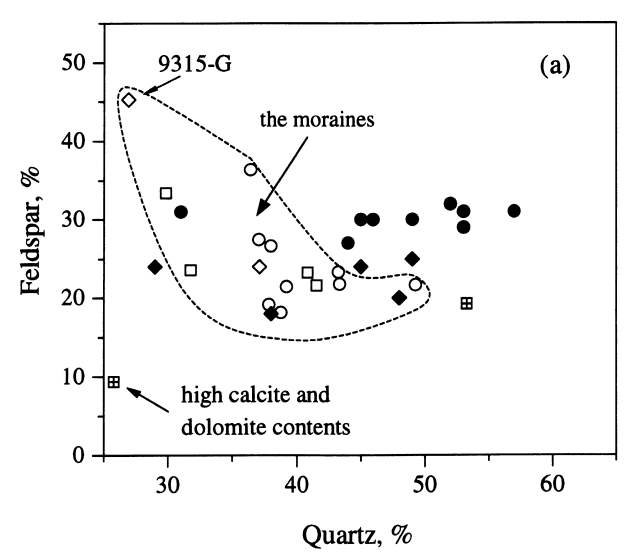

․ Moraine of north Tianshan Mts.

- North Taklimakan Desert sand $\diamond \quad$ Moraine of south Tianshan Mts.

- Southwest and central Taklimakan Desert sand

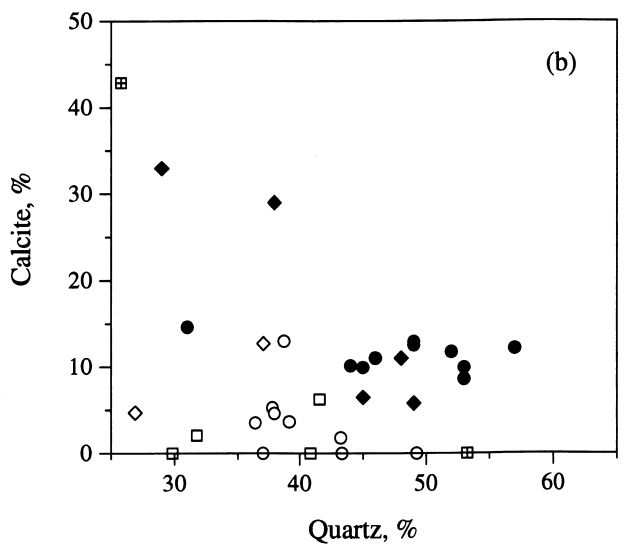

- Moraine of west Kunlun Mts.

田 Northwest Tibet soil

Fig. 3. (a) Quartz versus feldspar, and (b) quartz versus calcite abundance diagrams for the moraines and the desert sands. Data of southwest Taklimakan Desert sands are from Honda and Shimizu (1998).

\section{Major element compositions}

Major element data are given in Table 3 and average upper continental crust (UCC; Taylor and McLennan, 1985) normalized values are shown in Fig. 4. The sands from northern part of the Taklimakan Desert have very similar major element compositions to those from the south and central parts of the desert; all showing higher $\mathrm{CaO}$ content and lower $\mathrm{Na}_{2} \mathrm{O}$ and $\mathrm{K}_{2} \mathrm{O}$ content against UCC.

Compared with the Taklimakan Desert sands (this study; Honda and Shimizu, 1998), the moraine samples are more heterogeneous (Fig. 4). The UCC-normalized values for the moraine 


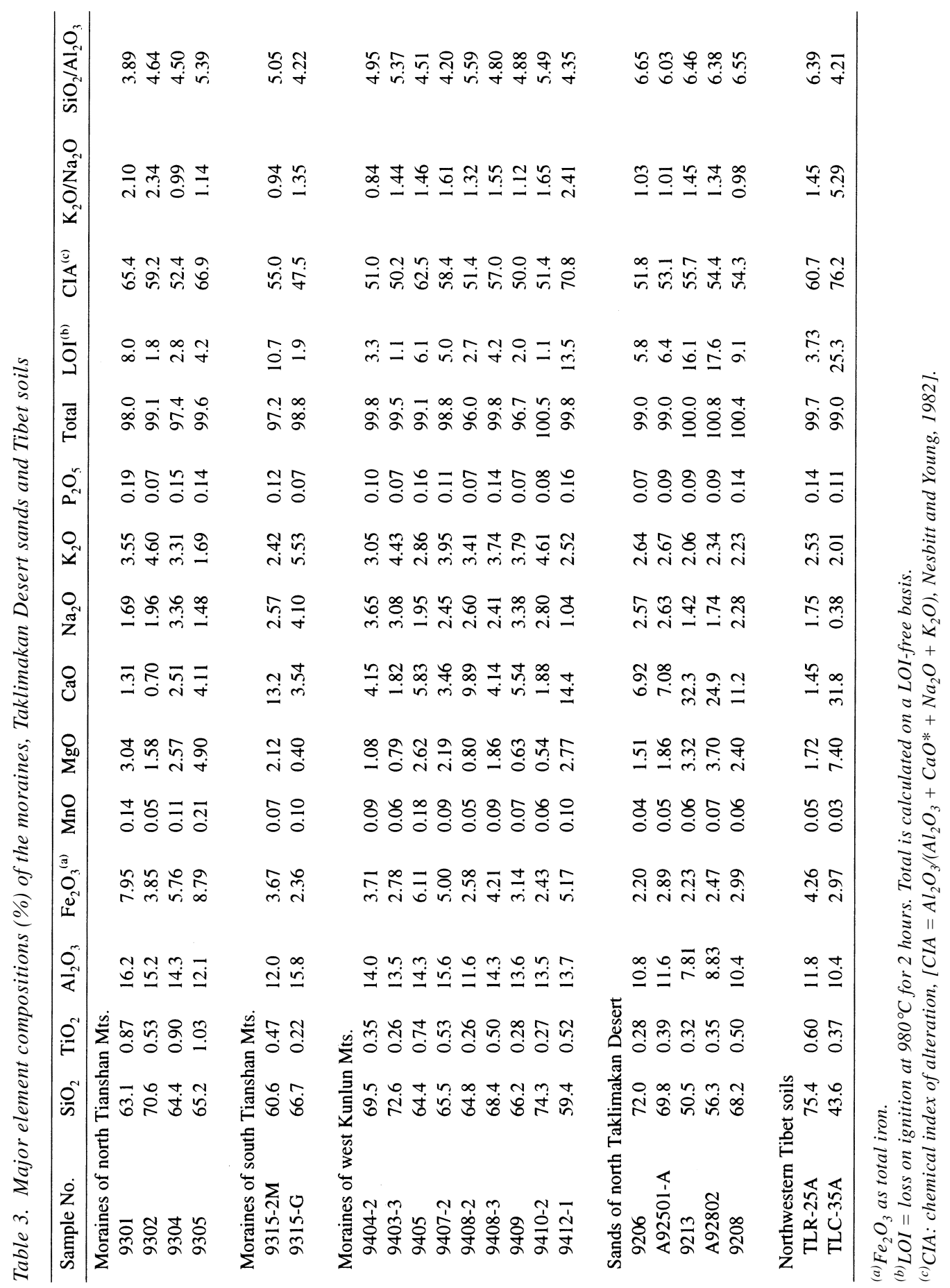




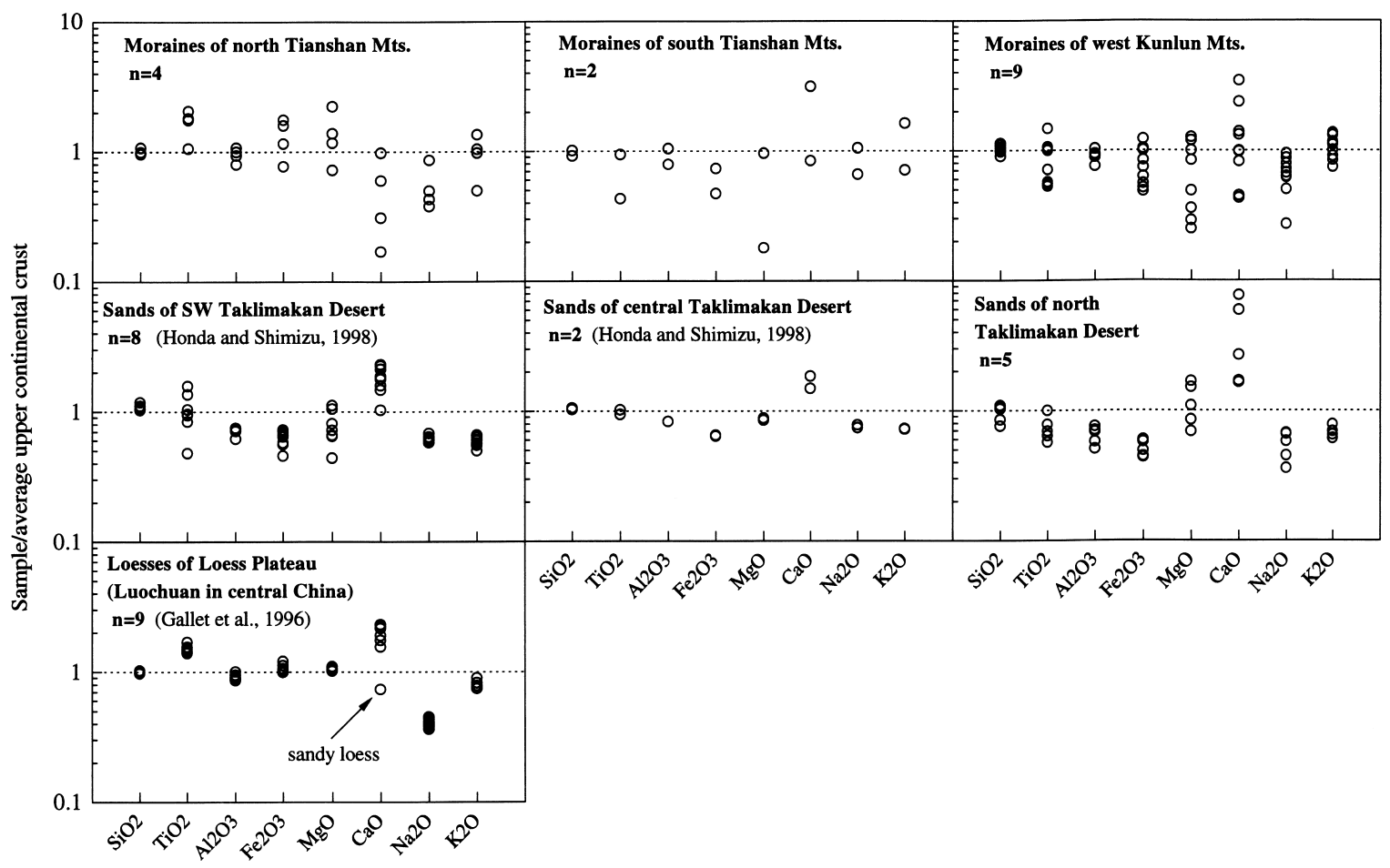

Fig. 4. UCC-normalized major element composition for the moraines, desert sands and loesses. The data of southwestern and central Taklimakan Desert sands are from Honda and Shimizu (1998) and the Luochuan loess are from Gallet et al. (1996). Average UCC values are from Taylor and McLennan (1985).

samples are 0.9-1.1 for $\mathrm{SiO}_{2}, 0.2-3.5$ for $\mathrm{CaO}$, 0.7-1.1 for $\mathrm{Al}_{2} \mathrm{O}_{3}, 0.4-2.3$ for $\mathrm{TiO}_{2}, \mathrm{MgO}$ and total iron as $\mathrm{Fe}_{2} \mathrm{O}_{3}, 0.3-1.0$ for $\mathrm{Na}_{2} \mathrm{O}$ and $0.5-1.6$ for $\mathrm{K}_{2} \mathrm{O}$. In accordance with the mineral composition difference between the moraines and desert sands, average $\mathrm{CaO}$ content are higher in the desert sands, and $\mathrm{K}_{2} \mathrm{O}, \mathrm{Al}_{2} \mathrm{O}_{3}$ and $\mathrm{Fe}_{2} \mathrm{O}_{3}$ are higher in the moraines (Fig. 5(a)). In spite of these differences and great heterogeneity, the average values of most major elements for 15 moraine samples show a general resemblance with the desert sands (Fig. 5(a)). This suggests that fine-grained subglacial deposits could be the source for the Taklimakan Desert sands. Regional variation of the major element compositions seems unclear between the Tianshan and Kunlun Mts. (Fig. 5(b)).

The correlation between $\mathrm{Fe}_{2} \mathrm{O}_{3}$ and $\mathrm{MgO}$ was clearly different for the moraines and desert sands (Fig. 6). Moraines show significant positive correlation between the two elements; the desert sands show relatively higher $\mathrm{MgO}$ in respect to $\mathrm{Fe}_{2} \mathrm{O}_{3}$ and poor correlation between them, indicating that $\mathrm{Fe}$ and $\mathrm{Mg}$ are hosted in different minerals in these two sediments. Mineral composition data have suggested abundant chlorite and amphibole minerals in moraines and higher dolomite content in the sands. Relatively low $\mathrm{Fe}_{2} \mathrm{O}_{3}$ of desert sands than the moraines and loess (Figs. 6 and 4) may imply the preferential distribution of chlorite during wind sorting of fine grains. However, further study on detailed mineral composition data of Chinese loess is needed to support such explanation.

Moraines differ from the desert sands in ratios of $\mathrm{SiO}_{2} / \mathrm{Al}_{2} \mathrm{O}_{3}$ and $\mathrm{K}_{2} \mathrm{O} / \mathrm{Na}_{2} \mathrm{O}$ as shown in Fig. 7 . $\mathrm{K}_{2} \mathrm{O} / \mathrm{Na}_{2} \mathrm{O}$ ratios are generally greater than $1.0 \mathrm{in}$ the moraines, but less than 1.0 for the desert sands. This difference may be due to higher mica contents in the moraines than in the desert sands. $\mathrm{SiO}_{2} /$ $\mathrm{Al}_{2} \mathrm{O}_{3}$ ratios of moraines vary from 3.8 to 5.6, 

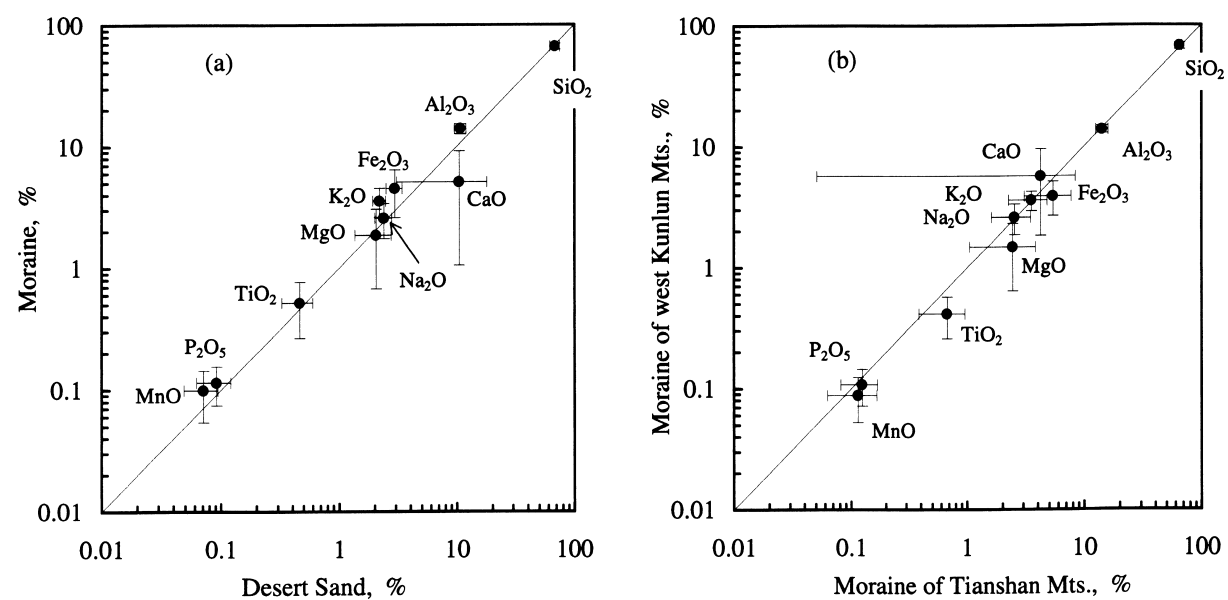

Fig. 5. Comparisons of average major element compositions (a) between the moraines and the Taklimakan Desert sands (this study and Honda and Shimizu, 1998), and (b) between moraines from the Kunlun and Tianshan Mts. Error bars correspond to $1 \sigma$ level.

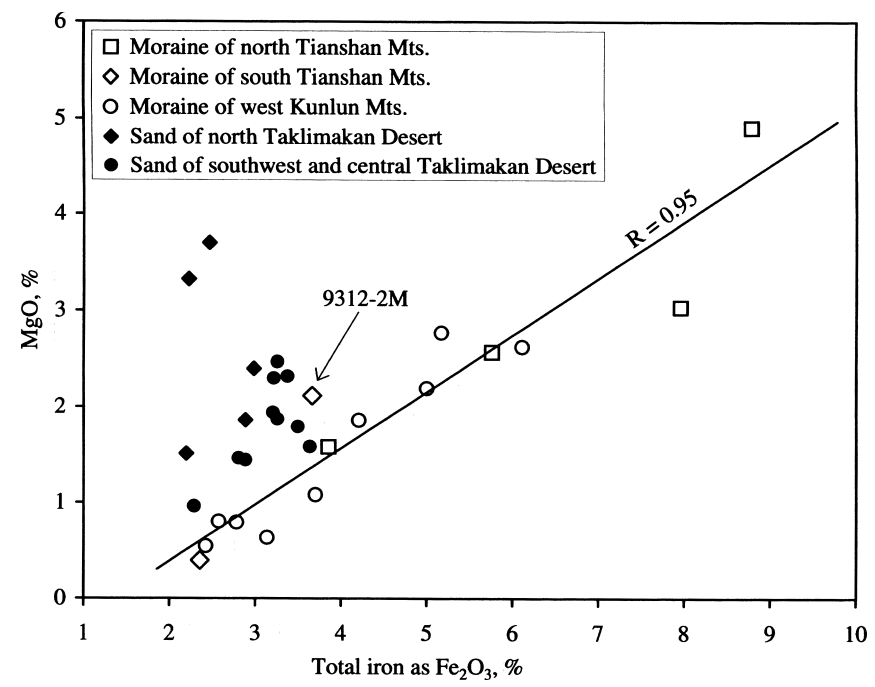

Fig. 6. $\mathrm{MgO}$ vs. total iron diagram for the moraines and the Taklimakan Desert sands, showing that MgO and $\mathrm{Fe}_{2} \mathrm{O}_{3}$ are associated in different minerals in the moraine and the desert sand.

being slightly higher than that of UCC but clearly lower than those of the Taklimakan Desert sands. Higher kaolinite content in the moraines than in the desert sands is consistent with lower $\mathrm{SiO}_{2} /$ $\mathrm{Al}_{2} \mathrm{O}_{3}$ ratios in the former than in the latter. XRD peak ratios of kaolinite/quartz in the moraines positively correlate with CIA (chemical index of alteration; Nesbitt and Young, 1982) values, as shown in Fig. 8. CIA was calculated as CIA = $\left[\mathrm{Al}_{2} \mathrm{O}_{3} /\left(\mathrm{Al}_{2} \mathrm{O}+\mathrm{CaO} *+\mathrm{Na}_{2} \mathrm{O}+\mathrm{K}_{2} \mathrm{O}\right)\right] \times 100$, in molecular proportion, where $\mathrm{CaO} *$ is the amount of $\mathrm{CaO}$ in silicate. $\mathrm{CaO}^{*}$ was calculated after Honda and Shimizu (1998), assuming the $\mathrm{Ca}: \mathrm{Na}$ ratio in plagioclase to be $1: 3$. CIA values of moraines vary from 47 to 71 (Table 3 ), which are consistent with typical values of Pleistocene till 


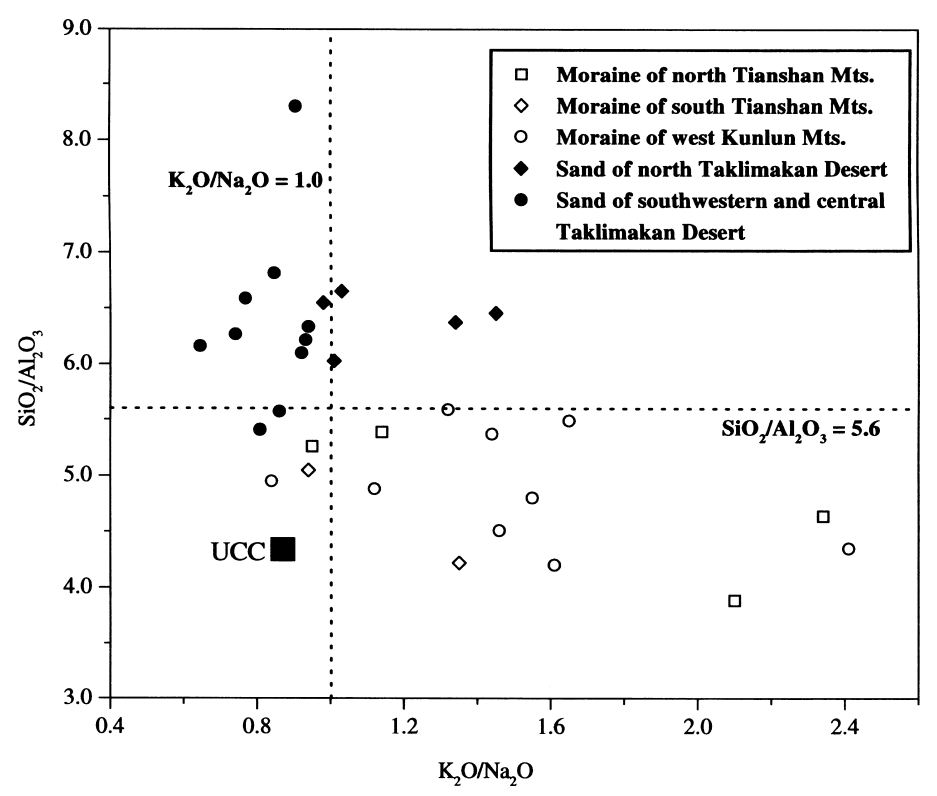

Fig. 7. Plot of $\mathrm{SiO}_{2} / \mathrm{Al}_{2} \mathrm{O}_{3}$ ratio against $\mathrm{K}_{2} \mathrm{O} / \mathrm{Na}_{2} \mathrm{O}$ ratio for the Kunlun and Tianshan Mts. moraines and the Taklimakan Desert sands (this study and Honda and Shimizu, 1998).

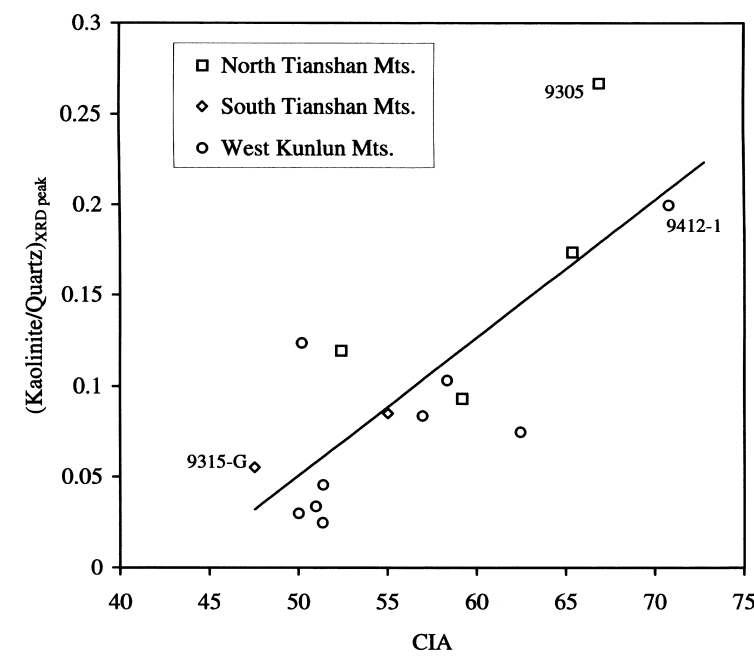

Fig. 8. Kaolinitelquartz XRD peak intensity ratios against CIA value for the Kunlun and Tianshan Mts. moraines.

matrix and glacial clays (Nesbitt and Young, 1982). This range partly overlaps that of the Taklimakan Desert sands (e.g., 52-56 in this study and the values reported by Honda and Shimizu, 1998) and on average, is slightly lower than that of loess of the Loess Plateau (Gallet et al., 1996).
CIA value originally indicates the degree of alteration of feldspars to clay minerals. However, moraines generally suffer from little chemical weathering, and kaolinite in the moraines is thought to be derived from sedimentary rocks before glacial moraine deposition. Therefore, large variations of CIA value and kaolinite content in the moraines reflect poor homogenization of glacial grinding process.

\section{Rare earth element (REE) abundances}

REE abundance data are given in Table 4 and chondrite-normalized patterns are shown in Fig. 9. All samples including the moraines, desert sands and soils show light REE enriched patterns with negative Eu anomalies, which are similar to that of UCC (Taylor and McLennan, 1985). Moraine samples show wide variations in $(\mathrm{La} / \mathrm{Yb})_{\mathrm{N}}$ and $\mathrm{Eu} / \mathrm{Eu}^{*}$ ratios with lower values in contrast to restricted and higher values for the Taklimakan Desert sand and Tarim loess (Liu et al., 1993) (Fig. 10(a)). Moreover, moraines from the north flank of the Tianshan Mts. tend to have smaller $(\mathrm{La} / \mathrm{Yb})_{\mathrm{N}}$ ratios than those from the western Kunlun Mts. and southern flank of the Tianshan Mts. The 


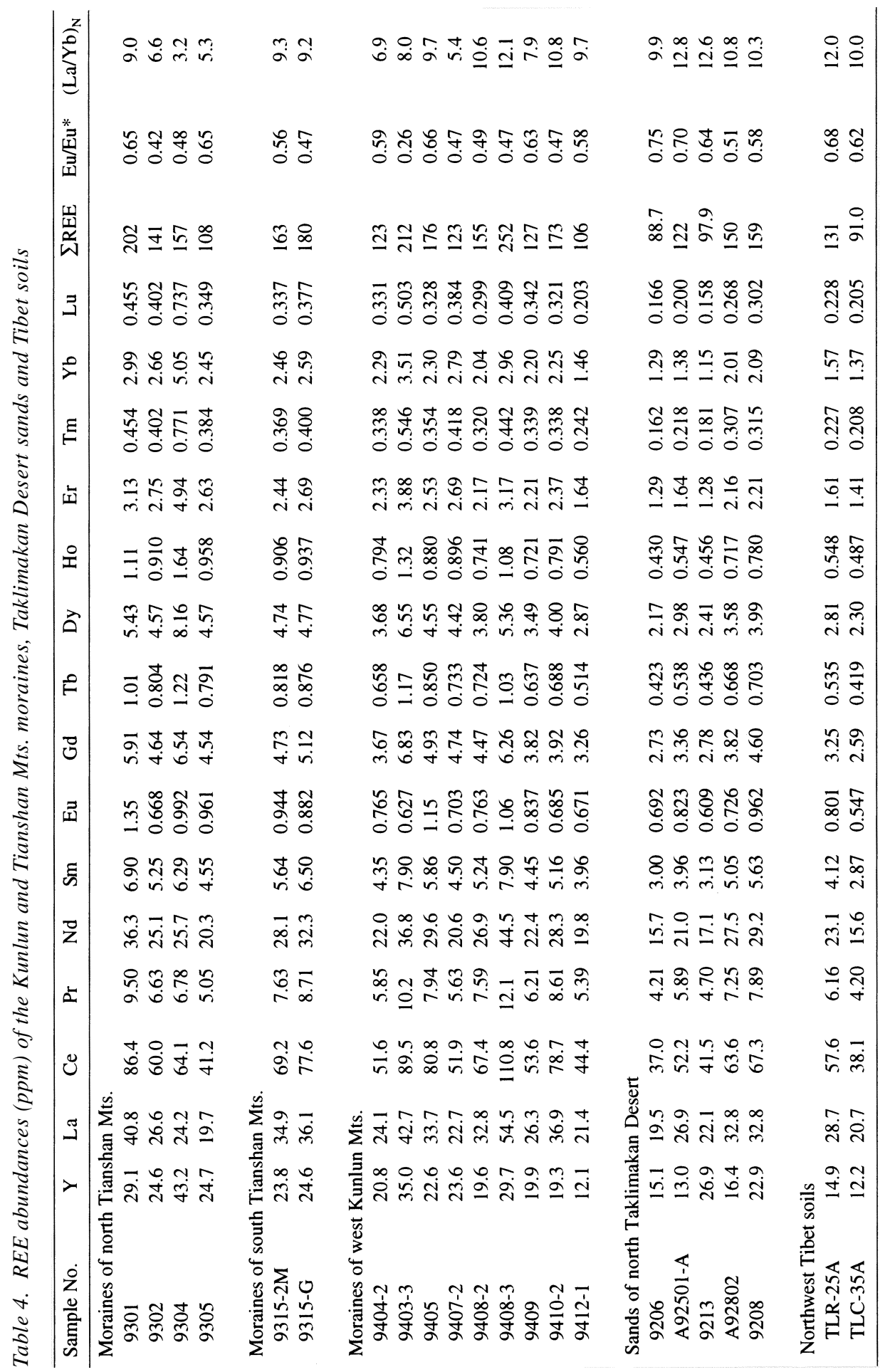




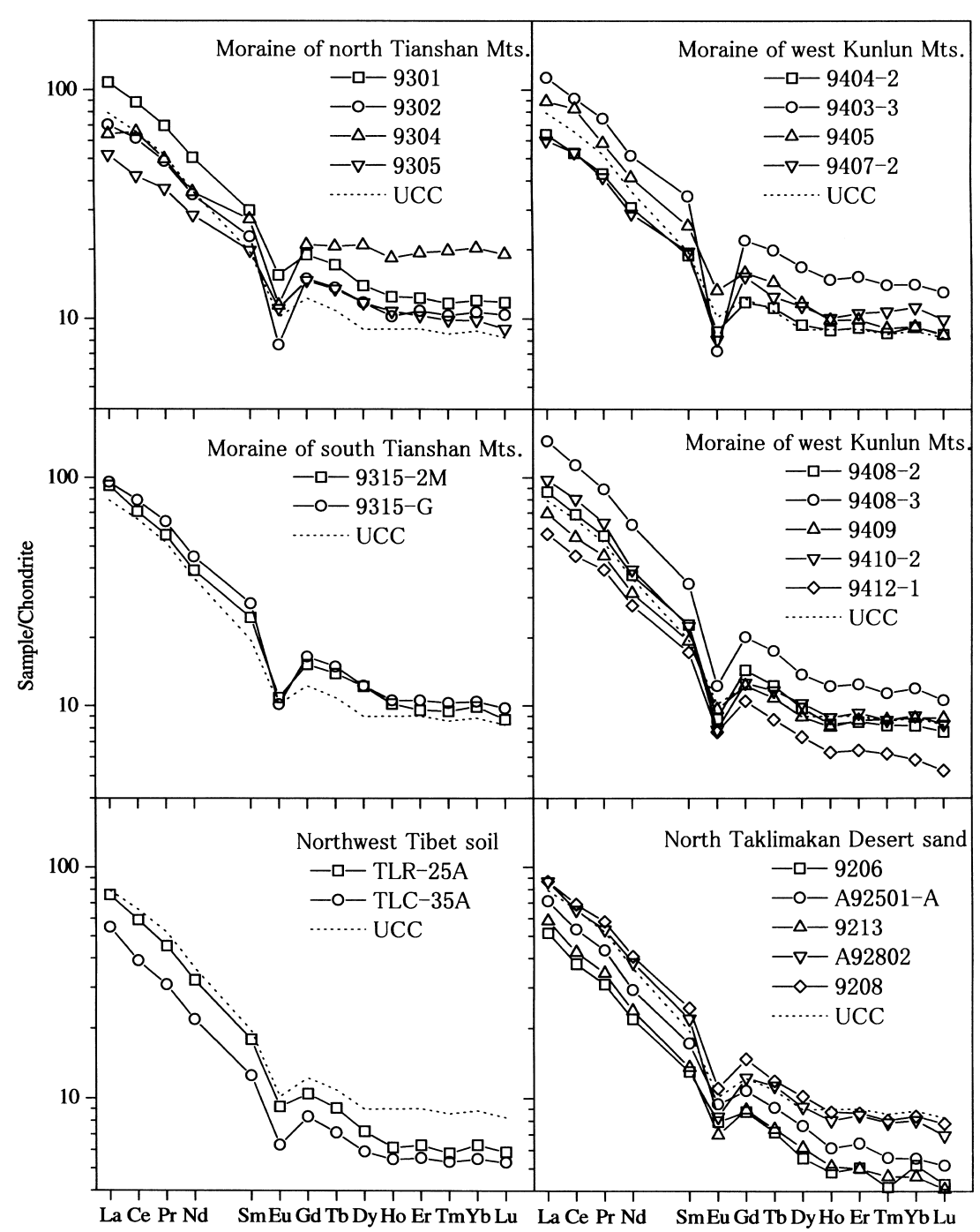

Fig. 9. Chondrite-normalized REE patterns of the Kunlun and Tianshan Mts. moraines, the Taklimakan Desert sands and Tibet soils. REE abundances in the Leedey chondrite (Masuda et al., 1973; Masuda, 1975) are used for normalization. For comparison the average REE composition of UCC (Taylor and McLennan, 1985) is shown as dashed line.

loesses of the Loess Plateau (Gallet et al., 1996, 1998) show slightly lower $(\mathrm{La} / \mathrm{Yb})_{\mathrm{N}}$ ratio but similar $\mathrm{Eu} / \mathrm{Eu}^{*}$ value to the Taklimakan Desert sands and Tarim loess. The Tibet soils are similar to the Taklimakan Desert sands and the Tarim loess in the $(\mathrm{La} / \mathrm{Yb})_{\mathrm{N}}$ and $\mathrm{Eu} / \mathrm{Eu}^{*}$ ratios. The $(\mathrm{La} / \mathrm{Yb})_{\mathrm{N}}$ ratio difference among the moraines, desert sands and loesses might be due to the grain-size difference and associated mineral sorting among these samples, as discussed below.
REE abundance variation with grain size fractions for the Kunlun moraine 9412-1 is given in Table 5 and the variation of $(\mathrm{La} / \mathrm{Yb})_{\mathrm{N}}$ ratio and $\mathrm{Nd}$ abundance with grain size is traced in Fig. 10(b). From the fraction $>500 \mu \mathrm{m}$ to the $20-32$ $\mu \mathrm{m}$ fraction, $(\mathrm{La} / \mathrm{Yb})_{\mathrm{N}}$ ratios and $\mathrm{Nd}$ abundances increase by a factor of 1.9 and 2.4, respectively. $(\mathrm{La} / \mathrm{Yb})_{\mathrm{N}}$ ratios and $\mathrm{Nd}$ abundances are 8.5 and $17 \mathrm{ppm}$ for the former fraction and 16 and $41 \mathrm{ppm}$ for the latter fraction, while the 9412-1 whole rock 

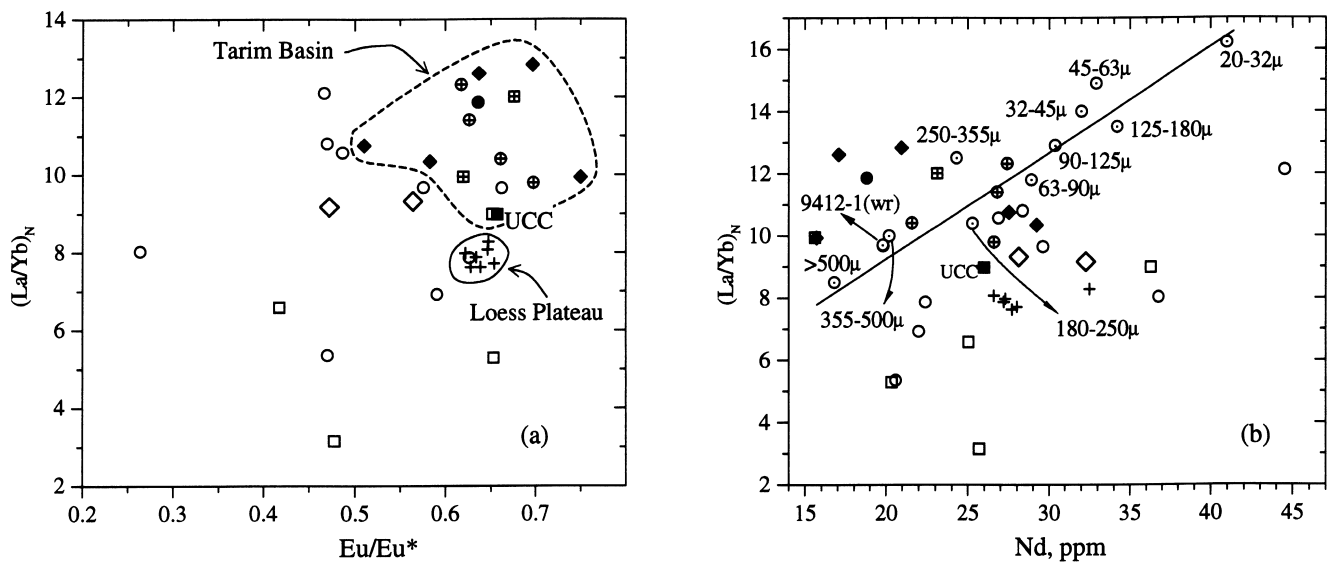

Moraine of north Tianshan Mts. $\diamond$ Moraine of south Tianshan Mts.

- Moraine of west Kunlun Mts. $\odot$ Size fraction of moraine of west Kunlun Mts. (9412-1)

- Sand of north Taklimakan Desert - Sand of southwest Taklimakan Desert

$\oplus$ Loess of southwest Tarim Basin $\quad+$ Loess of Loess Plateau

田 Northwest Tibet soil

Fig. 10. Plots of $(\mathrm{La} / \mathrm{Yb})_{N}-\mathrm{Eu} / \mathrm{Eu} *$ and $(\mathrm{La} / \mathrm{Yb})_{N^{-N}}$ d abundances for the Kunlun and Tianshan Mts. moraines and the Taklimakan Desert sands. Data of Loess Plateau are from Gallet et al. (1996); Tarim Basin loess and southwestern Taklimakan Desert sand from Liu et al. (1993).

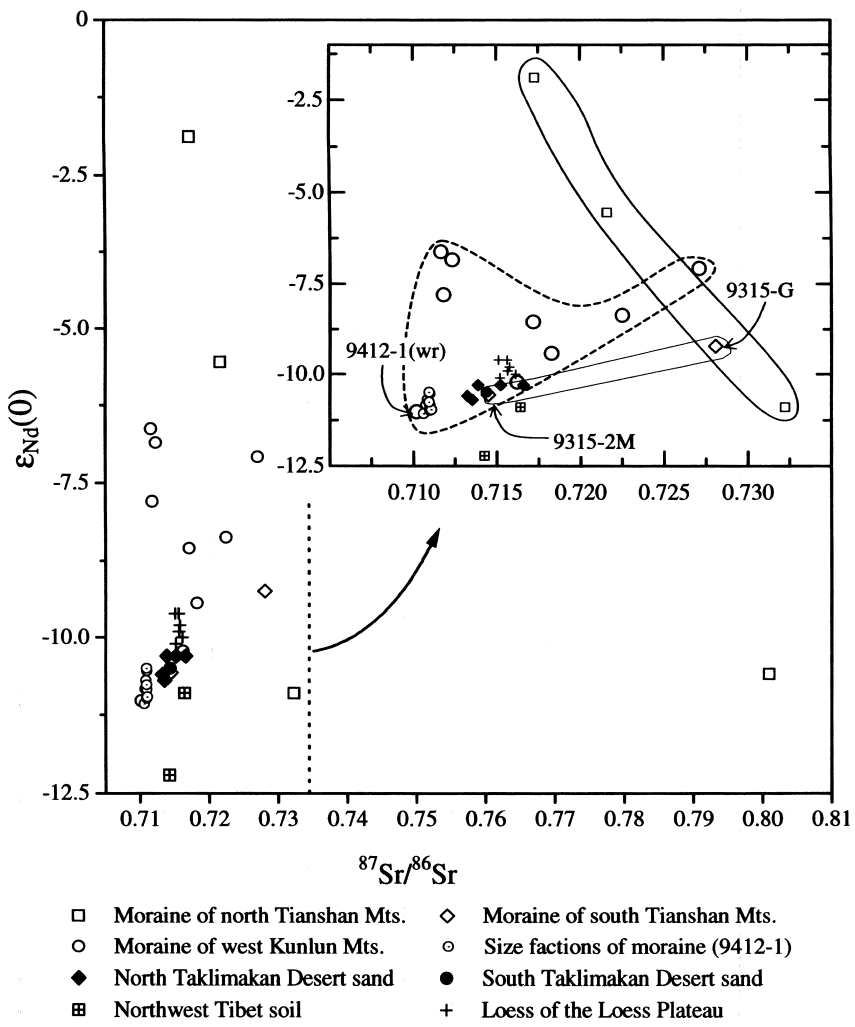

Fig. 11. $\varepsilon_{N d}(0)-{ }^{87} \mathrm{Sr} /{ }^{86} \mathrm{Sr}$ plot for the Kunlun and Tianshan Mts. moraines, the Taklimakan Desert sands and Tibet soils. The data of desert sands from the southwestern Taklimakan Desert (Liu et al., 1994) and those of Luochuan loesses (Gallet et al., 1996) are also plotted. 


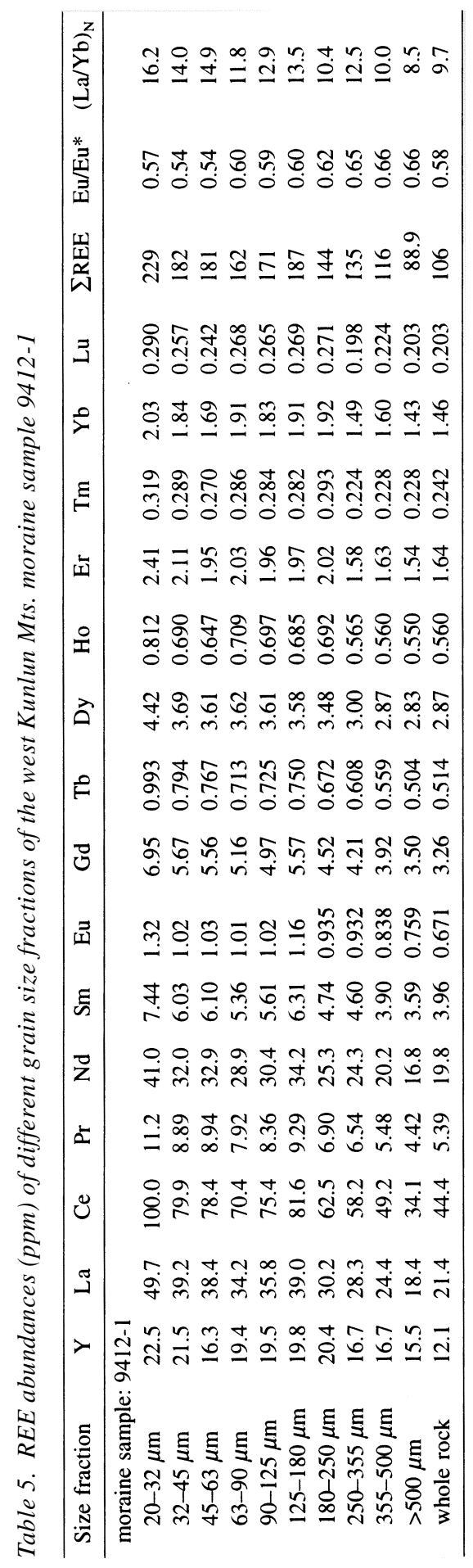

sample has $(\mathrm{La} / \mathrm{Yb})_{\mathrm{N}}$ ratio of 9.7 and $\mathrm{Nd}$ abundance of $20 \mathrm{ppm}$. Grain sizes of the Taklimakan Desert sands and the Loess Plateau loesses are chiefly $60-250 \mu \mathrm{m}$ and $10-40 \mu \mathrm{m}$ (e.g., Honda and Shimizu, 1998). Our result suggests some modifications in REE features by grain size sorting, which might take place during formation of the desert sand and loess from moraine. The modification in mineral composition during grain size sorting might responsible for the REE features differences among these deposits. It is noted that the variations of $(\mathrm{La} / \mathrm{Yb})_{\mathrm{N}}$ ratios and $\mathrm{Nd}$ abundances with grain size are comparable to those observed for the moraines and desert sands. Therefore, if the modification in REE feature with grain size sorting is considered, estimation of source for the desert sand and loess by direct comparison of $(\mathrm{La} / \mathrm{Yb})_{\mathrm{N}}$ ratio and REE abundance is difficult.

\section{Nd and Sr isotopic compositions}

$\mathrm{Nd}$ and $\mathrm{Sr}$ isotopic data are given in Table 6. For convenience in comparison, ${ }^{143} \mathrm{Nd} /{ }^{144} \mathrm{Nd}$ ratios are reported as $\varepsilon_{\mathrm{Nd}}$ notation (DePaolo and Wasserburg, 1976). The present-day $\varepsilon_{\mathrm{Nd}}(0)$ values are calculated by using the CHUR ${ }^{143} \mathrm{Nd} /{ }^{144} \mathrm{Nd}$ $=0.512638$ (Jacobsen and Wasserburg, 1980).

Moraine deposits are highly variable in both $\mathrm{Sr}$ and $\mathrm{Nd}$ isotopic compositions, compared with the desert sands (Fig. 11). In particular, moraines from the northern flank of Tianshan Mts. show extremely wide variations in ${ }^{87} \mathrm{Sr} /{ }^{86} \mathrm{Sr}$ ratio from 0.717 to 0.801 and $\varepsilon_{\mathrm{Nd}}(0)$ value from -1.9 to -11.0. Moraines from the western Kunlun Mts. are relatively less variation in ${ }^{87} \mathrm{Sr} /{ }^{86} \mathrm{Sr}$ ratios and $\varepsilon_{\mathrm{Nd}}(0)$ values, with ${ }^{87} \mathrm{Sr} /{ }^{86} \mathrm{Sr}$ ratios varying from 0.710 to 0.727 and $\varepsilon_{\mathrm{Nd}}(0)$ values from -6.6 to -11.0 , plotted in the lower ${ }^{87} \mathrm{Sr} /{ }^{86} \mathrm{Sr}$ ratio field than the moraines from the Tianshan north flank. Two moraine samples from south slope of the Tianshan Mts., matrix and gravel samples (9315-2M and 9315-G), show different ${ }^{87} \mathrm{Sr} /{ }^{86} \mathrm{Sr}$ ratios of 0.714 and 0.728 with similar $\varepsilon_{\mathrm{Nd}}(0)$ values of -9.2 and -10.6. In the $\varepsilon_{\mathrm{Nd}}(0){ }^{-87} \mathrm{Sr} /{ }^{86} \mathrm{Sr}$ diagram, the moraine matrix sample (9315-2M) from south flank of the Tianshan Mts. is plotted in the field of moraines from the western Kunlun Mts., while the moraine 
Table 6. Sr and Nd isotopic compositions of the Kunlun and Tianshan Mts. moraines, Taklimakan Desert sands and Tibet soils

\begin{tabular}{|c|c|c|c|c|c|c|c|c|c|c|}
\hline Sample No. & $\begin{array}{c}\mathrm{Sm} \\
(\mathrm{ppm})\end{array}$ & $\begin{array}{c}\mathrm{Nd} \\
(\mathrm{ppm})\end{array}$ & $\mathrm{Sm} / \mathrm{Nd}$ & ${ }^{147} \mathrm{Sm} /{ }^{144} \mathrm{Nd}$ & ${ }^{143} \mathrm{Nd} /{ }^{144} \mathrm{Nd}$ & $\varepsilon_{\mathrm{Nd}}(0)$ & $\begin{array}{c}\mathrm{Rb} \\
(\mathrm{ppm})\end{array}$ & $\begin{array}{c}\mathrm{Sr} \\
(\mathrm{ppm})\end{array}$ & ${ }^{87} \mathrm{Rb} /{ }^{86} \mathrm{Sr}$ & ${ }^{87} \mathrm{Sr} /{ }^{86} \mathrm{Sr}$ \\
\hline \multicolumn{11}{|c|}{ Moraines of north Tianshan Mts. } \\
\hline 9301 & 6.90 & 36.3 & 0.19 & 0.115 & $0.512079 \pm 7$ & -10.9 & 156 & 114 & 3.97 & $0.732220 \pm 29$ \\
\hline 9302 & 5.25 & 25.1 & 0.21 & 0.127 & $0.512073 \pm 7$ & -11.0 & 229 & 55.0 & 12.2 & $0.800929 \pm 22$ \\
\hline 9304 & 6.29 & 25.7 & 0.24 & 0.148 & $0.512542 \pm 6$ & -1.9 & 237 & 177 & 3.88 & $0.717288 \pm 22$ \\
\hline 9305 & 4.55 & 20.3 & 0.22 & 0.135 & $0.512354 \pm 14$ & -5.5 & 79.2 & 102 & 2.24 & $0.721583 \pm 20$ \\
\hline \multicolumn{11}{|c|}{ Moraines of south Tianshan Mts. } \\
\hline $9315-2 \mathrm{M}$ & 5.64 & 28.1 & 0.20 & 0.121 & $0.512096 \pm 8$ & -10.6 & 126 & 331 & 1.11 & $0.714474 \pm 21$ \\
\hline $9315-\mathrm{G}$ & 6.50 & 32.3 & 0.20 & 0.122 & $0.512165 \pm 6$ & -9.2 & 215 & 153 & 4.07 & $0.728077 \pm 23$ \\
\hline \multicolumn{11}{|c|}{ Moraines of west Kunlun Mts. } \\
\hline $9404-2$ & 4.35 & 22.0 & 0.20 & 0.120 & $0.512298 \pm 7$ & -6.6 & 117 & 303 & 1.12 & $0.711648 \pm 23$ \\
\hline $9403-3$ & 7.90 & 36.8 & 0.21 & 0.130 & $0.512275 \pm 7$ & -7.1 & 227 & 118 & 5.55 & $0.727085 \pm 22$ \\
\hline 9405 & 5.86 & 29.6 & 0.20 & 0.120 & $0.512114 \pm 7$ & -10.2 & 127 & 243 & 1.52 & $0.716220 \pm 20$ \\
\hline $9407-2$ & 4.50 & 20.6 & 0.22 & 0.132 & $0.512222 \pm 7$ & -8.1 & 270 & 236 & 3.32 & $0.717154 \pm 22$ \\
\hline $9408-2$ & 5.24 & 26.9 & 0.20 & 0.118 & $0.512238 \pm 8$ & -7.8 & 138 & 736 & 0.542 & $0.711796 \pm 20$ \\
\hline $9408-3$ & 7.90 & 44.5 & 0.18 & 0.107 & $0.512154 \pm 9$ & -9.4 & 159 & 180 & 2.57 & $0.718253 \pm 23$ \\
\hline 9409 & 4.45 & 22.4 & 0.20 & 0.120 & $0.512287 \pm 7$ & -6.9 & 160 & 522 & 0.884 & $0.712315 \pm 23$ \\
\hline $9410-2$ & 5.16 & 28.3 & 0.18 & 0.110 & $0.512209 \pm 8$ & -8.4 & 252 & 161 & 4.55 & $0.722497 \pm 23$ \\
\hline $9412-1$ & 3.96 & 19.8 & 0.20 & 0.121 & $0.512072 \pm 7$ & -11.0 & 174 & 621 & 0.813 & $0.710178 \pm 23$ \\
\hline \multicolumn{11}{|c|}{ Sands of north Taklimakan Desert } \\
\hline 9206 & 3.00 & 15.7 & 0.19 & 0.115 & $0.512109 \pm 8$ & -10.3 & 92.5 & 277 & 0.967 & $0.715209 \pm 19$ \\
\hline A92501-A & 3.96 & 21.0 & 0.19 & 0.114 & $0.512111 \pm 8$ & -10.3 & 98.1 & 259 & 1.10 & $0.716582 \pm 21$ \\
\hline 9213 & 3.13 & 17.1 & 0.18 & 0.111 & $0.512091 \pm 7$ & -10.7 & 78.8 & 239 & 0.953 & $0.713540 \pm 23$ \\
\hline A92802 & 5.05 & 27.5 & 0.18 & 0.111 & $0.512092 \pm 8$ & -10.6 & 71.7 & 261 & 0.796 & $0.713230 \pm 23$ \\
\hline 9208 & 5.63 & 29.2 & 0.19 & 0.116 & $0.512108 \pm 7$ & -10.3 & 74.9 & 266 & 0.815 & $0.713861 \pm 21$ \\
\hline \multicolumn{11}{|c|}{ Northwest Tibet soils } \\
\hline TLR-25A & 4.12 & 23.1 & 0.18 & 0.108 & $0.512079 \pm 7$ & -10.9 & 98.0 & 139 & 2.04 & $0.716402 \pm 21$ \\
\hline TLC-35A & 2.87 & 15.6 & 0.18 & 0.111 & $0.512012 \pm 8$ & -12.2 & 80.5 & 103 & 2.26 & $0.714245 \pm 18$ \\
\hline
\end{tabular}

Errors of isotopic ratios are $2 \sigma_{m}$ and correspond to the last significant figures.

gravel sample (9315-G) from the Tianshan south slope is in the moraines from Tianshan north flank. Two Tibet soils have ${ }^{87} \mathrm{Sr} /{ }^{86} \mathrm{Sr}$ ratios of 0.716 and 0.714 and $\varepsilon_{\mathrm{Nd}}(0)$ values of -10.9 and -12.1 , plotted in the lower $\varepsilon_{\mathrm{Nd}}(0)$ field than the western Kunlun moraines and the Taklimakan Desert sands (Fig. 11).

The Taklimakan Desert sands are restrictive in $\mathrm{Sr}$ and $\mathrm{Nd}$ isotopic compositions, with ${ }^{87} \mathrm{Sr} /{ }^{86} \mathrm{Sr}$ ratios between 0.713 and 0.716 and $\varepsilon_{\mathrm{Nd}}(0)$ values around -10.4 . These isotopic data are essentially the same with those reported for the sand from southwestern Taklimakan Desert (Liu et al., 1994), suggesting isotopic homogeneous feature for all Taklimakan Desert sands.
$\mathrm{Sr}$ isotopic ratios in the moraine and desert sand samples seem to depend on $\mathrm{CaO}$ content and $\mathrm{Sr}$ abundance as shown in ${ }^{87} \mathrm{Sr} /{ }^{86} \mathrm{Sr}-1 / \mathrm{Ca}$ and ${ }^{87} \mathrm{Sr} /{ }^{86} \mathrm{Sr}-1 / \mathrm{Sr}$ diagrams (Figs. 12 (a) and (b)). The data suggest a component having high $\mathrm{Ca}$ and $\mathrm{Sr}$ contents with low ${ }^{87} \mathrm{Sr} /{ }^{86} \mathrm{Sr}$ ratio around 0.710 . In addition, it is noted that $\mathrm{Sr}$ abundance in the desert sand samples have small range between 240 and 275 ppm irrespective of the large variation of $\mathrm{CaO}$ content (6-30\%, Fig. 12(c)). This observation implies low $\mathrm{Sr}$ contents in the secondary carbonates added to the desert sands.

$\mathrm{Sr}$ and $\mathrm{Nd}$ isotopic ratios of different grain size fractions of the moraine $9412-1$ are given in Table 7 and in Fig. 13, where ${ }^{87} \mathrm{Sr} /{ }^{86} \mathrm{Sr}$ ratios decrease 
from 0.7111 in $125-180 \mu \mathrm{m}$ fraction to 0.7106 in 20-32 $\mu \mathrm{m}$ fraction with constant $\varepsilon_{\mathrm{Nd}}(0)$ values between -10.5 and -11.0. As shown in the $\varepsilon_{\mathrm{Nd}}(0)$ ${ }^{87} \mathrm{Sr} /{ }^{86} \mathrm{Sr}$ diagram (Fig. 11), however, the $\mathrm{Sr}$ and $\mathrm{Nd}$ isotopic ratio variation with grain sizes is small, compared with the wide variations of these ratios among moraine samples. Therefore, the variation of isotopic ratio with grain size is negligible in discussing the source materials for the Taklimakan Desert sands.

In the $\varepsilon_{\mathrm{Nd}}(0)-{ }^{87} \mathrm{Sr} /{ }^{86} \mathrm{Sr}$ diagram (Fig. 11), the Taklimakan Desert sands are included in the field overlapped by both the moraines from western Kunlun Mts. and the Tianshan southern flank, but
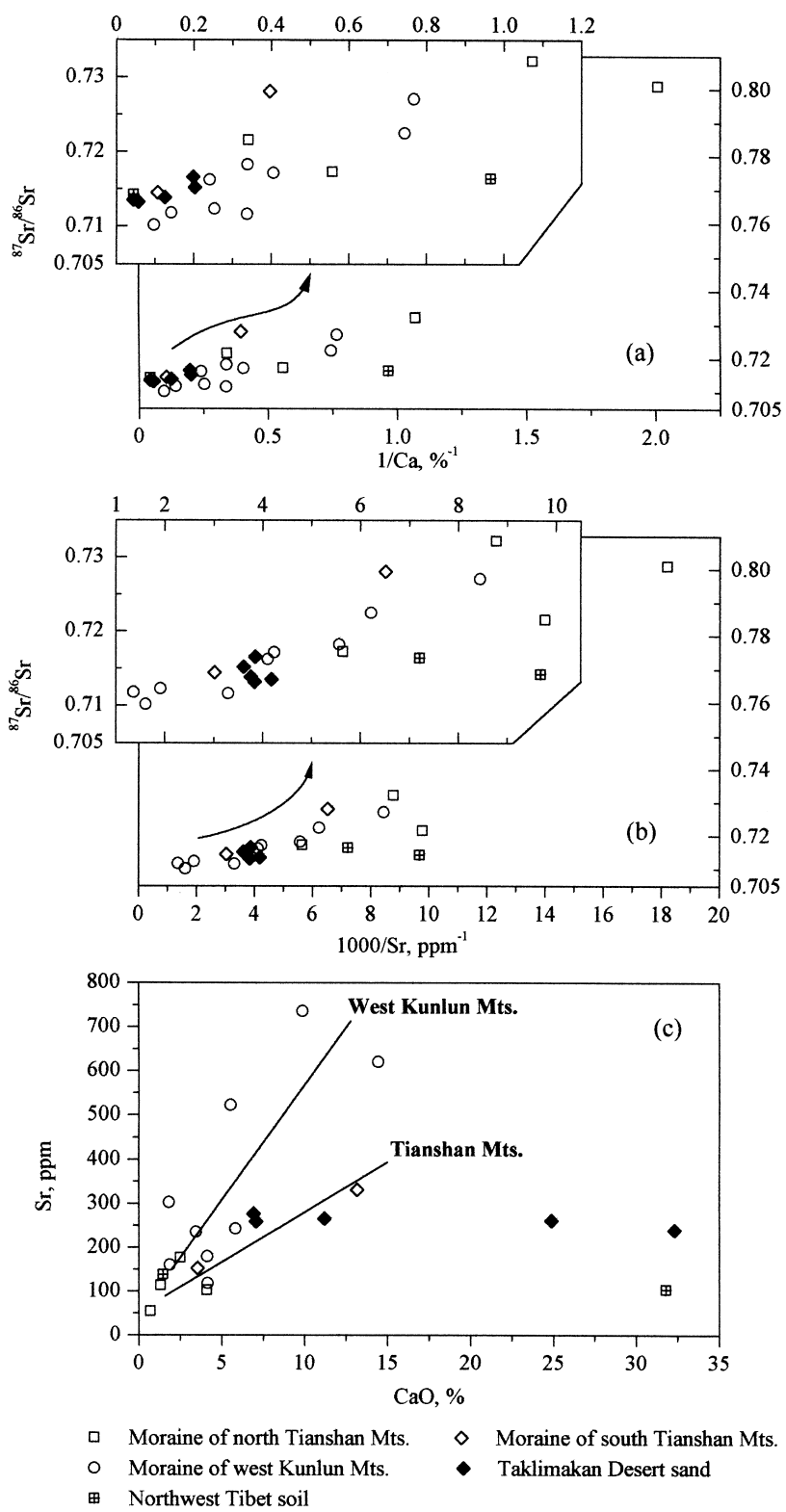

Fig. 12. (a) ${ }^{87} \mathrm{Sr} /{ }^{86} \mathrm{Sr}$ vs. $1 / \mathrm{Ca},\left(\right.$ b ${ }^{87} \mathrm{Sr} /{ }^{86} \mathrm{Sr} v$ s. $1 / \mathrm{Sr}$, and (c) CaO vs. Sr diagrams for the Kunlun and Tianshan Mts. moraines and the Taklimakan Desert sand of this study. 


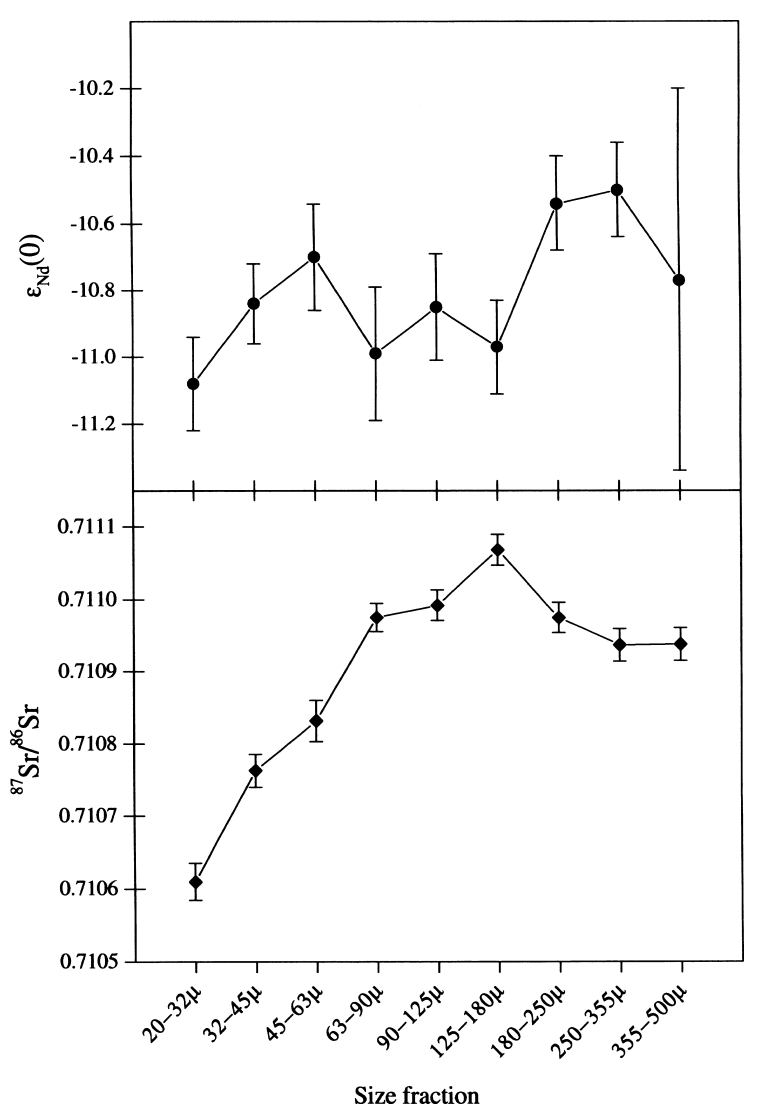

Fig. 13. Variation of ${ }^{87} \mathrm{Sr} /{ }^{86} \mathrm{Sr}$ ratios and $\varepsilon_{N d}(0)$ values with change of grain sizes (in $\mu \mathrm{m}$ ) of the Kunlun moraine sample 9412-1. Error bars are measurement errors in $2 \sigma$. separated from that of the Tianshan northern flank moraines. In addition, it is noted that the average ${ }^{87} \mathrm{Sr} /{ }^{86} \mathrm{Sr}$ ratios for the moraines from western Kunlun Mts. and from the Tianshan south flank are similar to that of the Taklimakan Desert sands, but the corresponding $\varepsilon_{\mathrm{Nd}}(0)$ values for the moraines are about $2 \varepsilon$ unit higher than for the sands (Fig. 14). The $\varepsilon_{\mathrm{Nd}}(0)$ value discrepancy between the moraines and the desert sands suggests a contribution from other sources for the Taklimakan Desert sands. One possibility is the contribution from the Tibet soils, which have smaller $\varepsilon_{\mathrm{Nd}}(0)$ value but similar ${ }^{87} \mathrm{Sr} /{ }^{86} \mathrm{Sr}$ ratio to the Taklimakan Desert sands. The mixture between the Tibet soils and the moraines from the western Kunlun Mts. and the Tianshan south flank will yield the ${ }^{87} \mathrm{Sr} /{ }^{86} \mathrm{Sr}$ ratio similar to those of the endmembers and $\varepsilon_{\mathrm{Nd}}(0)$ value between them (Fig. 14). Mixing calculation (Langmuir et al., 1978) using the average values of $\mathrm{Sr}$ and $\mathrm{Nd}$ isotopic and abundance data of the Kunlun moraines and Tibet soils shows that the $\mathrm{Sr}$ and $\mathrm{Nd}$ isotopic ratios for the ca. 2:3 mixture of the moraines and the Tibet soils generally agree with those for the desert sands. However, the $\mathrm{Sr}$ abundances calculated from the mixing model are lower in $30 \%$ than the observed values for the desert sands. Particle sorting and the addition of secondary calcite into the sands could explain the $\mathrm{Sr}$ abundance discrepancy. As

Table 7. Sr and Nd isotopic data of different grain size fractions of the Kunlun Mts. moraine sample 9412-1

\begin{tabular}{|c|c|c|c|c|c|c|c|c|c|c|}
\hline Size fraction & $\begin{array}{l}\text { Weight } \\
\text { percent }\end{array}$ & $\begin{array}{c}\mathrm{Sm} \\
(\mathrm{ppm})\end{array}$ & $\begin{array}{c}\mathrm{Nd} \\
(\mathrm{ppm})\end{array}$ & ${ }^{147} \mathrm{Sm} /{ }^{144} \mathrm{Nd}$ & ${ }^{143} \mathrm{Nd} /{ }^{144} \mathrm{Nd}$ & $\varepsilon_{\mathrm{Nd}}$ & $\begin{array}{c}\mathrm{Rb} \\
(\mathrm{ppm})\end{array}$ & $\begin{array}{c}\mathrm{Sr} \\
(\mathrm{ppm})\end{array}$ & ${ }^{87} \mathrm{Rb} /{ }^{86} \mathrm{Sr}$ & ${ }^{87} \mathrm{Sr} /{ }^{86} \mathrm{Sr}$ \\
\hline $20-32 \mu \mathrm{m}$ & 1.6 & 7 & 41.0 & 0.110 & $0.512070 \pm 7$ & -11.1 & 94.7 & 440 & 0.623 & $0.710610 \pm 26$ \\
\hline $32-45 \mu \mathrm{m}$ & 1.9 & 6.03 & 32.0 & 0.114 & $0.512082 \pm 6$ & -10.8 & 115 & 443 & 0.753 & $0.710763 \pm 23$ \\
\hline $45-63 \mu \mathrm{m}$ & 1.7 & 6.10 & 32.9 & 0.112 & $0.512089 \pm 8$ & -10.7 & 126 & 470 & 0.774 & $0.710831 \pm 28$ \\
\hline $63-90 \mu \mathrm{m}$ & 1.4 & 5.36 & 28.9 & 0.112 & $0.512075 \pm 10$ & -11.0 & 125 & 480 & 0.755 & $0.710975 \pm 20$ \\
\hline $90-125 \mu \mathrm{m}$ & 1.0 & 5.61 & 30.4 & 0.112 & $0.512082 \pm 8$ & -10.8 & 138 & 463 & 0.862 & $0.710992 \pm 21$ \\
\hline $125-180 \mu \mathrm{m}$ & 1.2 & 6.31 & 34.2 & 0.111 & $0.512076 \pm 7$ & -11.0 & 132 & 435 & 0.881 & $0.711068 \pm 21$ \\
\hline $180-250 \mu \mathrm{m}$ & 1.1 & 4.74 & 25.3 & 0.113 & $0.512098 \pm 7$ & -10.5 & 128 & 432 & 0.856 & $0.710975 \pm 21$ \\
\hline $250-355 \mu \mathrm{m}$ & 0.8 & 4.60 & 24.3 & 0.115 & $0.512100 \pm 7$ & -10.5 & 125 & 444 & 0.812 & $0.710936 \pm 23$ \\
\hline $355-500 \mu \mathrm{m}$ & 1.4 & 3.90 & 20.2 & 0.117 & $0.512086 \pm 30$ & -10.8 & 115 & 472 & 0.704 & $0.710937 \pm 23$ \\
\hline$>500 \mu \mathrm{m}$ & 88 & 3.59 & 16.8 & & & & 57.4 & 877 & 0.189 & $0.709443 \pm 23$ \\
\hline whole rock & & 3.96 & 19.8 & 0.121 & $0.512072 \pm 7$ & -11.0 & 174 & 621 & 0.813 & $0.710178 \pm 23$ \\
\hline \multicolumn{10}{|c|}{$<5 \mu \mathrm{m}$ fraction (leached with $1 \mathrm{~N}$ acetic acid) } & $0.711101 \pm 11$ \\
\hline
\end{tabular}

Errors are $2 \sigma_{m}$ and correspond to the last significant figures. 

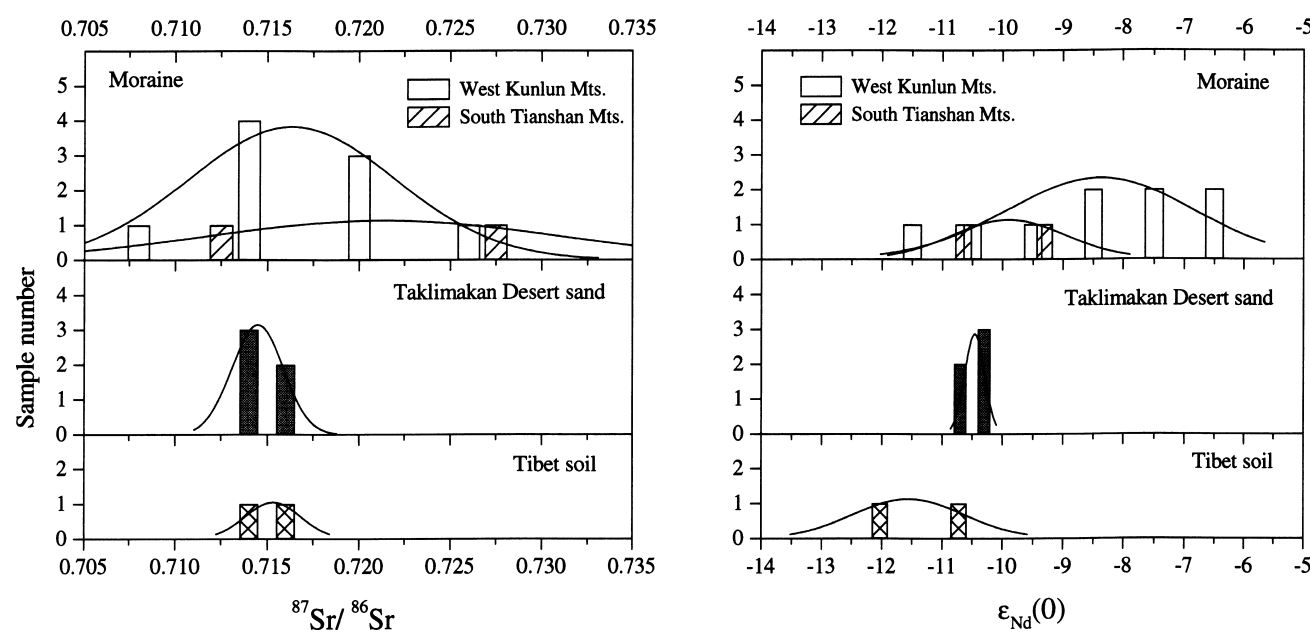

Fig. 14. Histograms of ${ }^{87} \mathrm{Sr} /{ }^{86} \mathrm{Sr}$ ratios and $\varepsilon_{N d}(0)$ values for the moraines, desert sands and Tibet soils.

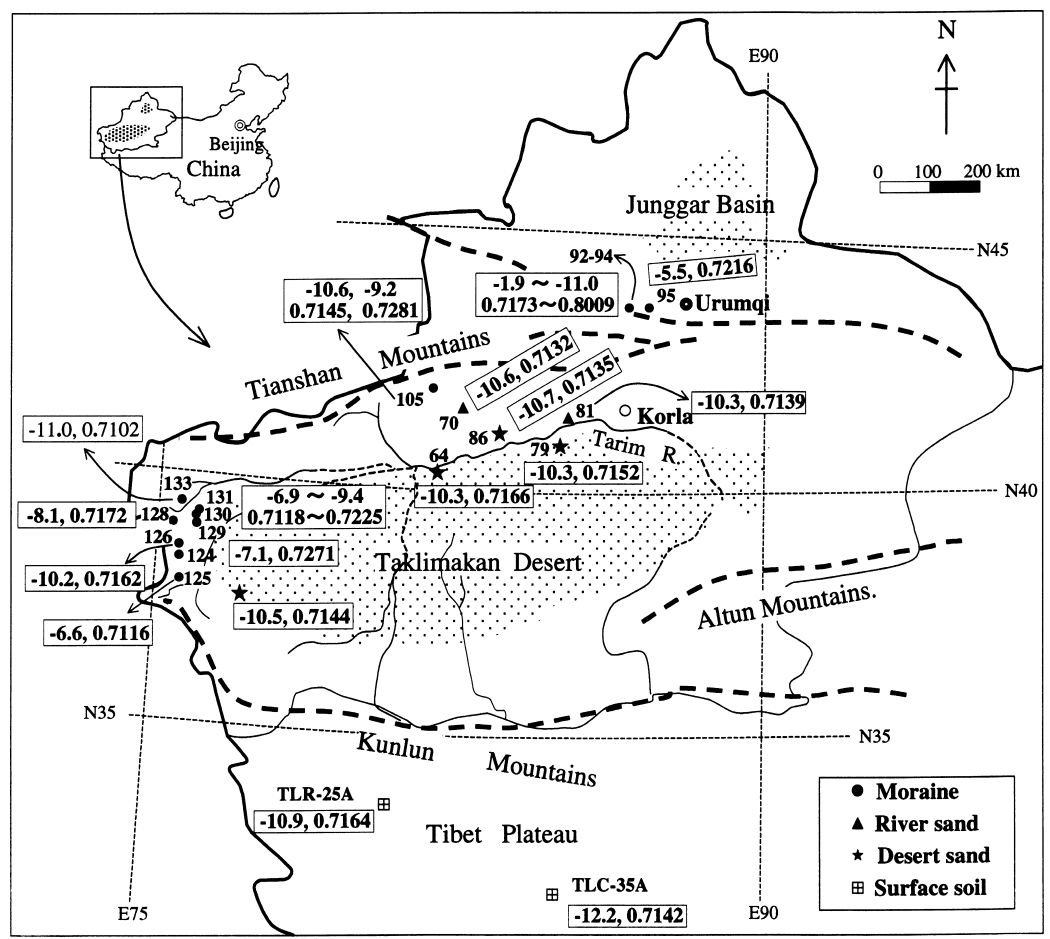

Fig. 15. Map showing Nd and Sr isotopic compositions of the moraines and Taklimakan Desert sands. Numbers are location number and those in boxes are the values of $\varepsilon_{N d}(0)$ and ${ }^{87} \mathrm{Sr} /{ }^{86} \mathrm{Sr}$. Data of desert sand of southwestern Taklimakan are from Liu et al. (1994). 
shown in Table 7, particle sorting has greater effect on $\mathrm{Sr}$ and $\mathrm{Nd}$ abundances than on the isotopic compositions. Although a statistical significance of the average isotopic values of the moraines is unclear because of wide variation of individual data, and the number of Tibet sample is limited, the mixing calculation suggests one of the possible models. In conclusion, these results imply that Kunlun Mts. and southern flank of Tianshan Mts. probably serve as source region for the desert sand, and that the Tibet Plateau also has made a considerable contribution to the Taklimakan Desert. It seems quite natural from the geographical viewpoint that the $\mathrm{Nd}$ and $\mathrm{Sr}$ isotopic data for the Taklimakan Desert sands fall not in the field for those from the northern flank of the Tianshan Mts., but in the field for the moraine matrix from the western Kunlun Mts. and southern flank of the Tianshan Mts. (Figs. 11 and 15).

\section{SUMMARY}

This paper reported the first systematic data of $\mathrm{Sr}$ and $\mathrm{Nd}$ isotopic compositions, REE and major element abundances and mineral composi- tion for the Chinese moraines from the western Kunlun Mts. and the Tianshan Mts., which are possible sources for the Taklimakan Desert sand and Chinese loess. The data were also reported for the soils from the northwest Tibet and the desert sands and river sands from the north side of the Taklimakan Desert. The results are summarized in Table 8. The following conclusions can be drawn from the present results.

1. Quartz and feldspars are the main constituent minerals both in the desert sands and in moraine deposits, although the desert sands show slightly higher quartz content than the moraines (40-50\% for the desert sands and 30-50\% for the moraines). Higher calcite contents in the desert sands $(>5 \%)$ than in the moraines $(<5 \%)$ are observed, suggesting an addition of secondary calcite to the desert sands. Mica and clay mineral contents are higher in the moraines.

2. Major element compositions of the moraines show wider variations than those of the desert sands. The average values of most major elements show general agreement between the moraines and desert sands, although $\mathrm{CaO}$ enrichment and $\mathrm{K}_{2} \mathrm{O}$ depletion are observed in the desert

Table 8. Summary of mineralogical and geochemical features for the moraines, Taklimakan Desert sands and northwestern Tibet soils

\begin{tabular}{|c|c|c|c|c|c|c|}
\hline & \multicolumn{3}{|c|}{ Moraines } & \multicolumn{2}{|c|}{ Taklimakan Desert sands } & \multirow[t]{2}{*}{ Northwestern Tibet soils } \\
\hline & NTM & STM & WKM & NTD & $\operatorname{CSWTD}^{(4)}$ & \\
\hline Quartz (\%) & $32 \sim 41(36)$ & $27 \sim 37$ (32) & $36 \sim 49(40)$ & $29 \sim 49(42)$ & $31 \sim 53(48)$ & $26 \sim 53(40)$ \\
\hline Feldspar $(\%)$ & $22 \sim 33(26)$ & $24 \sim 45$ (34) & $18 \sim 36(24)$ & $12 \sim 32(22)$ & $27 \sim 31(30)$ & $9 \sim 19$ (14) \\
\hline Calcite $(\%)$ & $0 \sim 6(<2)$ & $5 \sim 13(9)$ & $0 \sim 13(3)$ & $6 \sim 33(17)$ & $8 \sim 13(11)$ & $0 \sim 43(21)$ \\
\hline $\mathrm{SiO}_{2} / \mathrm{Al}_{2} \mathrm{O}_{3}$ & $3.9 \sim 5.4(4.6)$ & $4.2 \sim 5.0(4.6)$ & $4.2 \sim 5.6(4.9)$ & $6.0 \sim 6.6(6.4)$ & $5.4 \sim 8.3(6.3)$ & $4.2 \sim 6.4(5.3)$ \\
\hline $\mathrm{K}_{2} \mathrm{O} / \mathrm{Na}_{2} \mathrm{O}$ & $1.0 \sim 2.3(1.6)$ & $0.9 \sim 1.35(1.2)$ & $0.8 \sim 2.4(1.5)$ & $1.0 \sim 1.4(1.2)$ & $0.65 \sim 0.94(0.9)$ & $1.5 \sim 5.3(3.4)$ \\
\hline $\mathrm{CaO}(\%)$ & $0.7 \sim 4.1(2.2)$ & $3.5 \sim 13.2(8.4)$ & $1.8 \sim 14.4(5.7)$ & $6.9 \sim 32.3(16.5)$ & $4.3 \sim 9.7(7.5)$ & $1.5 \sim 31.8(16.6)$ \\
\hline$(\mathrm{La} / \mathrm{Yb})_{\mathrm{N}}$ & $3.2 \sim 9.0(6.0)$ & $9.2 \sim 9.3(9.2)$ & $5.4 \sim 12.1(9.0)$ & $9.9 \sim 12.8(11.3)$ & 11.9 & $10.0 \sim 12.0(11.0)$ \\
\hline $\mathrm{Eu} / \mathrm{Eu}^{*}$ & $0.42 \sim 0.65(0.55)$ & $0.47 \sim 0.56(0.52)$ & $0.26 \sim 0.66(0.51)$ & $0.51 \sim 0.75(0.63)$ & 0.64 & $0.62 \sim 0.68(0.65)$ \\
\hline $\mathrm{Nd}(\mathrm{ppm})$ & $20.3 \sim 36.3(26.8)$ & $28.1 \sim 32.3(30.2)$ & $19.8 \sim 44.5(27.9)$ & $15.7 \sim 29.2(22.1)$ & 18.8 & $15.6 \sim 23.1(19.4)$ \\
\hline${ }^{87} \mathrm{Sr} /{ }^{86} \mathrm{Sr}$ & $\begin{array}{c}0.7173 \sim 0.8009 \\
(0.7430)\end{array}$ & $\begin{array}{c}0.7145 \sim 0.7281 \\
\quad(0.7213)\end{array}$ & $\begin{array}{l}0.7102 \sim 0.7271 \\
\quad(0.7163)\end{array}$ & $\begin{array}{c}0.7132 \sim 0.7166 \\
\quad(0.7145)\end{array}$ & 0.7144 & $\begin{array}{l}0.7142 \sim 0.7164 \\
\quad(0.7153)\end{array}$ \\
\hline$\varepsilon_{\mathrm{Nd}}(0)$ & $\begin{array}{c}-1.9 \sim-11.0 \\
(-7.3)\end{array}$ & $\begin{array}{c}-9.2 \sim-10.6 \\
(-9.9)\end{array}$ & $\begin{array}{c}-6.6 \sim-11.0 \\
(-8.4)\end{array}$ & $\begin{array}{c}-10.3 \sim-10.7 \\
(-10.4)\end{array}$ & -10.5 & $\begin{array}{c}-10.9 \sim-12.1 \\
(-11.6)\end{array}$ \\
\hline
\end{tabular}

NTM = northern Tianshan Mts., STM = southern Tianshan Mts., WKM = western Kunlun Mts., NTD = northern Taklimakan Desert, CSWTD = central and southwestern Taklimakan Desert. Number in bracket is average value.

${ }^{(a)}$ Data for central and southwest Taklimakan Desert are from Honda and Shimizu (1998), Liu et al. (1993, 1994). 
sands, compared with the moraines. Moraines show lower $\mathrm{SiO}_{2} / \mathrm{Al}_{2} \mathrm{O}_{3}$ ratio than the desert sands. These minor differences in major element compositions might be explained by the minor difference in mineral compositions between the moraines and desert sands; higher mica and kaolinite contents and lower calcite contents in the former than in the latter.

3. Moraines show REE features similar to those of desert sand and loess, with some difference in inclination of REE patterns. For the moraine sample, however, finer grain size fractions tend to have larger inclination in REE patterns and higher REE abundances than the coarser fractions by a factor around 2, suggesting minor modifications in REE features by grain size sorting. This result implies that estimation of sources for the desert sands and loesses is hard by simple comparison of inclination in REE patterns and REE abundance.

4. Moraine deposits are highly variable in both $\mathrm{Sr}$ and $\mathrm{Nd}$ isotopic compositions, compared with the Taklimakan Desert sands. ${ }^{87} \mathrm{Sr} /{ }^{86} \mathrm{Sr}$ and $\varepsilon_{\mathrm{Nd}}(0)$ vary from 0.717 to 0.801 and from -1.9 to 11.0 for the Tianshan north flank moraines, from 0.714 to 0.728 and from -9.2 to -10.6 for the Tianshan south flank moraines and from 0.710 to 0.727 and from -6.6 to -11.0 for the Kunlun moraines. The Taklimakan Desert sands show narrow ranges of ${ }^{87} \mathrm{Sr} /{ }^{86} \mathrm{Sr}$ ratios between 0.713 and 0.716 and $\varepsilon_{\mathrm{Nd}}(0)$ values around -10.4 , plotted near the moraine matrix sample from the Tianshan south flank and in the lower $\varepsilon_{\mathrm{Nd}}(0)$ region of the western Kunlun moraines in the ${ }^{87} \mathrm{Sr} /{ }^{86} \mathrm{Sr}-\varepsilon_{\mathrm{Nd}}(0)$ diagram. The $\mathrm{Nd}$ isotopic data of the Taklimakan Desert sands are slightly higher than those of the Tibet soils. These isotopic data imply that the Taklimakan Desert sands were derived not from the Tianshan north flank moraines, but from the Tianshan south flank moraines, the Kunlun moraines and the Tibet soils.

5. Our mineralogical and isotopic data as well as chemical data for the desert sands from the north side of the Taklimakan Desert are essentially identical to those for the desert sands from the south and central parts of the Taklimakan Desert, show- ing specifically the homogeneity of the Taklimakan Desert sands.

Acknowledgments-We are grateful to T. Ishii (Geological Survey of Japan) for offering the moraine and desert sand samples and helpful information on them. S. Yoneda and H. Ozaki (National Science Museum) and Y. Shibata and H. Ishisako (Hiroshima University) are appreciated for their helps on mass spectrometer analysis and electron microprobe analysis. We thank C. Dragusanu (Hiroshima University), M. Honda (Institute of Physical and Chemical Research) and S. Nohda, H. Shibuya and H. Matsuda (Kumamoto University) for their valuable discussions. The manuscript is greatly improved based on detailed reviews and constructive comments from B.-m. Jahn and an anonymous reviewer. This study is supported by a Grant-in-Aid for Scientific Research from the Ministry of Education, Science, Sports and Culture of Japan. Part of this study was performed through Special Coordination Funds for promoting Science and Technology of STA (Science and Technology Agency), the Japanese Government.

\section{REFERENCES}

Asahara, Y., Tanaka, T., Kamioka, H., Nishimura, A. and Yamazaki, T. (1999) Provenance of the north Pacific sediments and process of source material transport as derived from $\mathrm{Rb}-\mathrm{Sr}$ isotopic systematics. Chem. Geol. 158, 271-291.

Basile, I., Grousset, F. E., Revel, M., Petit, J. R., Biscaye, P. E. and Barkov, N. I. (1997) Patagonian origin of glacial dust deposited in East Antarctica (Vostok and Dome C) during stages 2, 4 and 6. Earth Planet. Sci. Lett. 146, 573-589.

Bureau of Geology and Mineral Resources of Xinjiang Uygur Autonomous Region (1993) Regional Geology of Xinjiang Uygur Autonomous Region. Geol. Pub. House, Beijing, 841 pp. (in Chinese with English abstract).

Deer, W. A., Howie, R. A. and Zussman, J. (1992) An Introduction to the Rock-Forming Minerals. 2nd ed., Longman Scientific \& Technical, 647 pp.

DePaolo, D. J. and Wasserburg, G. J. (1976) Inferences about magma sources and mantle structure from variations of ${ }^{143} \mathrm{Nd} /{ }^{144} \mathrm{Nd}$. Geophys. Res. Lett. 3, 743746.

Derbyshire, E. (1996) Quaternary glacial sediments, glaciation style, climate and uplift in the Karakoram and northwest Himalaya: review and speculations. Palaeogeogr. Palaeoclimatol. Palaeoecol. 120, $147-$ 157.

Dragusanu, C. and Tanaka, T. (1999) 1.57-Ga 
magmatism in the south Carpathians: implication for the Pre-Alpine basement and evolution of mantle under the European continent. J. Geol. 107, 237-248.

Gallet, S., Jahn, B.-m. and Torii, M. (1996) Geochemical characterization of the Luochuan loesspaleosol sequence, China, and paleoclimatic implications. Chem. Geol. 133, 67-88.

Gallet, S., Jahn, B.-m., Lanoe, B. Van Vliet, Dia, A. and Rossello, E. (1998) Loess geochemistry and its implications for particle origin and composition of the upper continental crust. Earth Planet. Sci. Lett. 156, 157-172.

Goldstein, S. L., O’Nions, R. K. and Hamilton, P. J. (1984) A Sm-Nd isotopic study of atmospheric dust and particulates from major river systems. Earth Planet. Sci. Lett. 70, 221-236.

Grousset, F. E., Biscaye, P. E., Revel, M., Petit, J. R., Pye, K., Joussaume, S. and Jouzel, J. (1992) Antartic (Dome C) ice-core dust at 18 k.y. B.P.: Isotopic constraints on origins. Earth Planet. Sci. Lett. 111, 175182.

Honda, M. and Shimizu, H. (1998) Geochemical, mineralogical and sedimentological studies on the Taklimakan Desert sands. Sedimentology 45, 11251143.

Ishii, T., Isobe, I., Mizuno, K., Kanai, Y., Matsuhisa, Y., Mizota, C., Qian, Y. B., Terashima, S. and Okumura, K. (1995) Study of the formation processes and sedimentary environments of surface geological features in desertic areas of China, with special reference to the characteristics and origin of eolian sediments. Bull. Geol. Surv. Japan 46, 651-685 (in Japanese with English abstract).

Jacobsen, S. B. and Wasserburg, G. J. (1980) Sm-Nd isotopic evolution of chondrites. Earth Planet. Sci. Lett. 50, 139-155.

Langmuir, C. H., Vocke, R. D., Jr., Hanson, G. N. and Hart, S. R. (1978) A general mixing equation with application to Icelandic basalts. Earth Planet. Sci. Lett. 37, 380-392.

Liu, C. Q., Masuda, A., Okada, A., Yabuki, S., Zhang, J. and Fan, Z.-L. (1993) A geochemical study of loess and desert sand in northern China: implications for continental crust weathering and composition. Chem. Geol. 106, 359-374.

Liu, C. Q., Masuda, A., Okada, A., Yabuki, S. and Fan, Z.-L. (1994) Isotopic geochemistry of Quaternary deposits from the arid lands in northern China. Earth Planet. Sci. Lett. 127, 25-38.

Masuda, A. (1975) Abundances of monoisotopic REE, consistent with the Leedey chondrite values.
Geochem. J. 9, 183-184.

Masuda, A., Nakamura, N. and Tanaka, T. (1973) Fine structures of mutually normalized rare-earth patterns of chondrites. Geochim. Cosmochim. Acta 37, 239248.

Matsuhisa, Y., Mizota, C., Faure, K. and Qian, Y. B. (1996) Homogenization processes of fine particles in the arid regions of western China, inferred from oxygen isotope composition of quartz. Abstracts of Todai International Symposium on Cosmochronology and Isotope Geoscience, 29-32.

Miyazaki, T. and Shuto, K. (1998) Sr and Nd isotope ratios of twelve GSJ rock reference samples. Geochem. J. 32, 345-350.

Nesbitt, H. W. and Young, G. M. (1982) Early Proterozoic climates and plate motions inferred from major element chemistry of lutite. Nature 299, 715717.

Shimizu, H., Yoshimura, J., Yamashita, M., Takahashi, K. and Adachi, M. (2000) Rb-Sr isotopic and REE geochemistry on garnet-biotite granodiorite clasts from the Permian Kozaki Formation, Kumamoto, Southwest Japan: A slightly enriched initial Sr isotope ratio and M-type REE tetrad pattern. Geochem. J. 34, 101-120.

Smalley, I. J. (1966) The properties of glacial loess and the formation of loess deposits. J. Sedimentary Petrology 36, 669-676.

Smalley, I. J. and Vita-Finzi, C. (1968) The formation of fine particles in sandy deserts and the nature of 'desert' loess. J. Sedimentary Petrology 38, 766-774.

Tanaka, T., Ando, N., Kamioka, H. and Togashi, S. (1990) Chemical compositions and ${ }^{138} \mathrm{Ce} /{ }^{142} \mathrm{Ce}$, ${ }^{143} \mathrm{Nd} /{ }^{144} \mathrm{Nd}$ and ${ }^{87} \mathrm{Sr} /{ }^{86} \mathrm{Sr}$ ratios of Takla Makan Desert sand. J. Mass Spectrom. Soc. Japan 38, 133141.

Tanaka, T., Tanimizu, M., Asahara, Y., Yonezawa, C., Togashi, S. and Kamioka, H. (1996) A variety of ${ }^{143} \mathrm{Nd} /{ }^{144} \mathrm{Nd}$ ratios among six high purity neodymium oxide reagents. J. Mass Spectrom. Soc. Japan 44, 79-83.

Taylor, S. R. and McLennan, S. M. (1985) The Continental Crust: Its Composition and Evolution. Blackwell Scientific Publications, 312 pp.

Xinjiang Institute of Geography, Chinese Academy of Sciences (1986) The Evolution of Tianshan Mountains. Science Press, Beijing, 188 pp. (in Chinese).

Zheng, B., Jiao, K., Ma, Q., Li, S. and Fushimi, H. (1990) The evolution of Quaternary glaciers and environmental changes in the West Kunlun Mountains, Western China. Bull. Glacier Res. 8, 61-72. 